\title{
Estrous cycle characterisation and artificial insemination using frozen-thawed spermatozoa in the bottlenose dolphin (Tursiops truncatus)
}

\author{
TR Robeck, KJ Steinman ${ }^{1}, M$ Yoshioka ${ }^{2}$, E Jensen $^{3}$, JK O$^{\prime}$ Brien $^{4}$, E Katsumata $^{5}, \mathrm{C} \mathrm{Gili}^{6}$, \\ JF McBain ${ }^{7}$, J Sweeney ${ }^{8}$ and SL Monfort ${ }^{1}$
}

SeaWorld Texas, 10500 SeaWorld Drive, San Antonio, TX 78251, USA, ${ }^{1}$ Conservation and Research Center, National Zoological Park, Smithsonian Institution, Front Royal, VA 22630, USA, ${ }^{2}$ Laboratory of Fish Culture, Faculty of Bioresources, Mie University, Tsu, Mie 514-8507, Japan, ${ }^{3}$ US Navy Marine Mammal Program, San Diego, CA 92152, USA, ${ }^{4}$ Centre for Advanced Technologies in Animal Genetics and Reproduction, Faculty of Veterinary Science, University of Sydney, Sydney, NSW 2006, Australia, ${ }^{5}$ Kamogawa SeaWorld, Kamogawa, Chiba 296-0041, Japan, ${ }^{6}$ Acquario di Genova, Ponte Spinola 16128, Genova, Italy, ${ }^{7}$ SeaWorld California, 500 SeaWorld Drive, San Diego, CA 92109, USA and ${ }^{8}$ Dolphin Quest Oahu, 5000 Kahala Ave, Honolulu, HI 96816, USA

Correspondence should be addressed to Todd R Robeck; Email: Todd.Robeck@SeaWorld.com

\begin{abstract}
The reproductive endocrinology of the bottlenose dolphin, Tursiops truncatus, was characterized to facilitate the development of artificial insemination using cryopreserved spermatozoa. Specific objectives were: (i) to determine the excretory dynamics of urinary luteinizing hormone (LH) and ovarian steroid metabolites during the estrous cycle; (ii) to evaluate the effect of an exogenously administered synthetic progesterone analog (altrenogest) on reproductive hormone excretion; (iii) to correlate follicular growth and ovulation (as determined by transabdominal ultrasound) to urinary LH and ovarian steroid metabolites; (iv) examine the in vivo fertilisation capacity of cryopreserved semen, and ( $v$ ) to develop an intrauterine insemination technique. Based on urinary endocrine monitoring of natural estrous cycles ( 2 consecutive cycles) and nine post altrenogest cycles in ten females, estrous cycles were found to be 36 days long and comprised of an 8 day and 19 day follicular and luteal phase, respectively. Peak estrogen conjugates (EC; $5.4 \pm 3.8 \mathrm{ng} / \mathrm{mg}$ creatinine $(\mathrm{Cr})$ ) occurred $8 \mathrm{~h}$ prior to the $\mathrm{LH}$ surge

$(70.9 \pm 115.7 \mathrm{ng} / \mathrm{mg} \mathrm{Cr})$. The time of ovulation, as determined by ultrasonography, occurred $32.1 \pm 8.9 \mathrm{~h}$ and $24.3 \pm 7.0 \mathrm{~h}$ after the onset of the LH surge and LH peak, respectively. Mean preovulatory follicular diameter and circumference were $2.1 \pm 0.5 \mathrm{~cm}$ and $6.5 \pm 1.5 \mathrm{~cm}$, respectively. Of the 27 estrous synchronisation attempts, 13 resulted in an ovulatory cycle, with ovulation occurring 21 days post-altrenogest treatment. Intrauterine (4 of 5) and intracornual (1 of 3) inseminations conducted across eight estrous cycles resulted in five pregnancies $(63 \%)$, one pregnancy resulted from the use of liquid stored semen, whereas four were achieved using cryopreserved semen. These data provide new information on female bottlenose dolphin reproductive physiology, and demonstrate that the combination of endocrine monitoring and serial ultrasonography contributed to successful Al using liquid-stored and cryopreserved semen.

Reproduction (2005) 129 659-674
\end{abstract}

\section{Introduction}

Reproductive success in the bottlenose dolphin (Tursiops truncatus), the most common cetacean held in captivity, has reached a point that parallels or exceeds that observed in wild populations (Duffield et al. 2000, Wells 2000). Despite a large captive population, most animals are dispersed among numerous genetically isolated facilities. Although movement of animals between facilities can enable genetic exchange, many aquaria are unwilling to participate in this management practice. This reluctance to cooperate or share genetics between facilities has resulted in poor founder animal penetration and is often associated with over representation of dominant animals (Duffield et al. 2000). The development and application of artificial insemination $(\mathrm{Al})$ in conjunction with genome resource banking would provide a mechanism to improve genetic management without animal transportation. However, before Al can be successfully developed in any 
species, basic questions concerning the reproductive physiology of that species must be answered.

Similarly to killer whales (Duffield et al. 1995), bottlenose dolphins can be readily trained for unrestrained blood sample collections. Progesterone and estrogen analysis of these samples demonstrated that bottlenose dolphins could spontaneously ovulate, have an estimated 21 to 42 days estrous cycle (Benirschke et al. 1980, Kirby \& Ridgway 1984, Schroeder 1990) and that estrogens are elevated from 5-7 days (Schroeder 1990). In addition, bottlenose dolphins have varying seasonal reproductive activity, ranging from polyestrous, seasonally polyestrous, to anestrous for one to two year intervals (Cornell et al. 1977, Cornell et al. 1987, Kirby \& Ridgway 1984, Kirby 1990, Schroeder 1990). Recent data suggest that the time of year when females are reproductively active may depend on the geographical location where they or their founder was originally collected (Urian et al. 1996).

Efforts to fully define serum hormonal profiles (reproductive steroids and gonadotropins) of the bottlenose dolphin around ovulation have not been entirely successful (Sawyer-Steffan \& Kirby 1980, Sawyer-Steffan et al. 1983, Schneyer et al. 1985, Yoshioka et al. 1986). Preovulatory estradiol (E2) levels observed in one animal ranged from 125 to $200 \mathrm{pg} / \mathrm{ml}$ (Yoshioka et al. 1986). With IndoPacific bottlenose dolphins (Tursiops aduncus), ovarian ultrasound was combined with serum hormone analysis to obtain similar E2 levels as reported previously (Yoshioka et al. 1986), but defined the serum estrogen profile as erratic and not useful for predicting ovulation (Brook 2000). Collection and analysis of urinary hormonal profiles as has been described for the killer whale (Walker et al. 1988, Robeck et al. 1993, 2004), would provide increased sampling frequency and may help resolve the endocrine dynamics during the peri-ovulatory period.

Ultrasonographic monitoring of ovarian follicular activity in bottlenose dolphin has been described previously (Brook 2000, Robeck et al. 1998). In the IndoPacific bottlenose dolphin, Brook (2000) defined the preovulatory follicle diameter (POF; range 17-23 mm) and documented a mean inter-ovulation interval of $\sim 30$ days. Importantly, the former study found that, for each animal POF sizes were similar between successive ovulations. Thus, predicting ovulation based on POF size was possible only after POF attributes had been characterized for that animal.

Altrenogest, a synthetic progestagen has been used to synchronize estrous in horses (Webel \& Squires 1982) and pigs (Kraeling et al. 1981) without affecting fertility in the female (Squires et al. 1979, Stevenson \& Davis 1982, Squires et al. 1983) In cetaceans, altrenogest has been used for long-term suppression of ovulation (Young \& Huff 1996) and to synchronize estrous in the killer whale (Orcinus orca), Pacific white-sided dolphin (Lagenorhynchus obliquidens) and bottlenose dolphin (Robeck et al. 2000, $2003,2004)$. The ability to control the timing of ovulation in bottlenose dolphins would allow for improved management of natural breeding and for timing of Al.

Methods of cryopreservation of bottlenose dolphin sperm using pellets or straws on dry ice or in liquid nitrogen vapor have been reported previously (Seager et al. 1981, Schroeder \& Keller 1990, Durrant et al. 2000, Robeck et al. 2001, Robeck \& O'Brien 2004). Despite these efforts, in vivo competence of frozen-thawed spermatozoa has never been demonstrated. The successful application of Al using frozen-thawed bottlenose dolphin spermatozoa would validate such preservation methods.

Artificial insemination has recently been successful using liquid-stored and cryopreserved spermatozoa in the killer whale and Pacific white-sided dolphin (Robeck et al. 2003, 2004) and using fresh extended sperm in the Indopacific bottlenose dolphin (Tursiops aduncus; Robeck et al. 2001, FM Brook et al., unpublished). Only ultrasound data were used in the latter study to determine timing for $\mathrm{Al}$, as a result, multiple inseminations were required prior to ovulation. By relying on peak urinary estrogen conjugates (EC) and urinary luteinizing hormone (LH) to time inseminations in the killer whale and Pacific white-sided dolphin, respectively, fewer inseminations prior to ovulation were required (Robeck et al. 2003, 2004). The development of a urinary LH assay system for the bottlenose dolphin may provide a consistent predictor of ovulation and allow a more efficient use of valuable semen. In addition, the development of $\mathrm{Al}$ using cryopreserved semen would enable the global exchange of genetic material and provide a tool for future application of genome resource banking (Holt et al. 1996, Wildt et al. 1997). Furthermore, the application of other assisted reproductive technologies, such as sperm sexing, may then be integrated into dolphin captive breeding programs.

The overall goal of this research was to gain a sufficient level of understanding of bottlenose dolphin reproductive physiology to develop Al using cryopreserved semen. To accomplish this, specific objectives were: (i) to determine the excretory dynamics of urinary LH and ovarian steroid metabolites during the estrous cycle; (ii) to evaluate the effect of an exogenously administered synthetic progesterone analog (altrenogest) on reproductive hormone excretion; (iii) to correlate follicular growth and ovulation (as determined by transabdominal ultrasound) to urinary $\mathrm{LH}$ and ovarian steroid metabolites; (iv) to examine the in vivo fertilisation capacity of cryopreserved semen, and (v) to develop an intrauterine insemination technique.

\section{Materials and Methods}

\section{Animals}

Thirteen adult, proven breeding female bottlenose dolphins (Tursiops truncatus) located at five facilities were used in endocrine monitoring and in Al trials (Table 1). Female 1, located at the Dolphin Quest Facility in Oahu, Hawaii, was used only for endocrine monitoring. This female was housed in an approximately $1233 \mathrm{~m}^{3}$ natural 
Table 1 Description of animals used and samples collected during the study.

\begin{tabular}{|c|c|c|c|c|c|c|c|c|}
\hline Animal & Facility $^{a}$ & Sex & Age & Weight & Reproductive history & Sample date range ${ }^{b}$ & No. of samples & Contribution $^{\mathrm{C}}$ \\
\hline 1 & DQ & $\mathrm{F}$ & 14 & 167 & Nulliparous & $06-05-02$ to $05-08-02$ & 71 & EC, LH, UP \\
\hline 2 & SWC & $\mathrm{F}$ & 22 & 286 & 1 stillborn, 1 calf & $20-01-04$ to $31-03-04$ & $\begin{array}{l}85 \\
32\end{array}$ & $\begin{array}{l}\text { ES, ultrasound, } \\
\text { EC, LH, UP }\end{array}$ \\
\hline \multirow[t]{3}{*}{3} & \multirow{3}{*}{ SWC } & \multirow[t]{3}{*}{$\mathrm{F}$} & \multirow[t]{3}{*}{14} & \multirow[t]{3}{*}{233} & \multirow{3}{*}{2 calves } & $15-06-03$ to $06-12-03$ & 159 & \multirow{3}{*}{$\begin{array}{l}\text { ES, ultrasound, } \\
\text { EC, LH, UP }\end{array}$} \\
\hline & & & & & & $20-01-04$ to $31-03-04$ & 86 & \\
\hline & & & & & & $05-05-04$ to $23-05-04$ & 31 & \\
\hline \multirow{2}{*}{4} & \multirow{2}{*}{ SWC } & \multirow{2}{*}{$\mathrm{F}$} & \multirow[t]{2}{*}{15} & \multirow{2}{*}{145} & \multirow{2}{*}{1 calf } & $24-02-04$ to $15-03-04$ & 36 & \multirow{5}{*}{$\begin{array}{l}\text { EC, LH, UP, ES, } \\
\text { Ultrasound } \\
\text { ES, ultrasound, EC } \\
\text { LH, UP }\end{array}$} \\
\hline & & & & & & $17-05-04$ to $17-06-04$ & 55 & \\
\hline \multirow[t]{3}{*}{5} & \multirow[t]{3}{*}{ SWC } & \multirow[t]{3}{*}{$\mathrm{F}$} & \multirow[t]{3}{*}{24} & \multirow[t]{3}{*}{218} & \multirow[t]{3}{*}{5 calves } & $15-06-03$ to $06-12-03$ & 170 & \\
\hline & & & & & & $20-01-04$ to $31-03-04$ & 90 & \\
\hline & & & & & & $05-05-04$ to $23-05-04$ & 33 & \\
\hline \multirow[t]{2}{*}{6} & USN & \multirow[t]{2}{*}{$\mathrm{F}$} & \multirow[t]{2}{*}{20} & 205 & 1 calf & $14-06-04$ to $30-06-04$ & 27 & ES, ultrasound, EC \\
\hline & MMP & & & & & & & LH, UP \\
\hline 7 & SWC & $\mathrm{F}$ & 12 & 231 & 1 calf & $07-05-02$ to $27-06-02$ & 27 & $\begin{array}{l}\text { ES, ultrasound, AI, } \\
\text { EC, LH, UP }\end{array}$ \\
\hline 8 & SWC & $\mathrm{F}$ & 11 & 235 & Nulliparous & $07-05-02$ to $27-06-02$ & 26 & $\begin{array}{l}\text { ES, ultrasound, AI, } \\
\text { EC, LH, UP }\end{array}$ \\
\hline 9 & KSW & $\mathrm{F}$ & 21 & 273 & 4 calves, 1 abortion & No urine samples & & $\mathrm{ES}$, ultrasound, $\mathrm{Al}$ \\
\hline 10 & KSW & $\mathrm{F}$ & 36 & 287 & 7 calves, 2 abortions & No urine samples & & ES, ultrasound, $\mathrm{Al}$ \\
\hline 11 & KSW & $\mathrm{F}$ & 17 & 265 & Nulliparous & No urine samples & & $\mathrm{ES}$, ultrasound, $\mathrm{Al}$ \\
\hline 12 & GA & $\mathrm{F}$ & 20 & 180 & 1 abortion & $16-07-03$ to $07-10-03$ & 67 & $\mathrm{ES}$, ultrasound, $\mathrm{AI}$, \\
\hline & & & & & 1 calf (1997) & $15-04-04$ to $03-07-04$ & 81 & EC, LH, UP \\
\hline 13 & SWC & $\mathrm{F}$ & 25 & 140 & 1 previous calf & $10-08-03$ to $08-12-03$ & 111 & $\mathrm{ES}$, ultrasound, $\mathrm{Al}$, \\
\hline & & & & & & $25-01-04$ to $13-03-04$ & 56 & EC, LH, UP \\
\hline & & & & & & $16-05-04$ to $08-07-04$ & 75 & \\
\hline 1 & USN & M & 24 & 183 & No previous sired calves & $16-05-02$ & $2 \mathrm{Ejac}^{\mathrm{d}}$ & Cryopreserved \\
\hline 2 & $\begin{array}{l}\text { MMP } \\
\text { SWC }\end{array}$ & M & 35 & 238 & Sired 10 calves, and 1 stillborn & $06-03-03$ & 1 Ejac & $\begin{array}{l}\text { semen } \\
\text { Cryopreserved }\end{array}$ \\
\hline & & & & & & & & semen \\
\hline 3 & KSW & M & 17 & 330 & 2 calves, 1 abortion & $02-07-02$ to $04-07-02$ & 3 Ejac & $\begin{array}{l}\text { Liquid stored } \\
\text { semen }\end{array}$ \\
\hline 4 & KSW & M & 20 & 365 & 8 calves, 1 abortion & 06-11-92 & 1 Ejac & Cryopreserved \\
\hline & & & & & & $21-06-93$ to $07-07-93$ & 5 Ejac & semen \\
\hline
\end{tabular}

${ }^{a}$ DQ, Dolphin Quest; SWC, SeaWorld California; USNMMP, US Navy Marine Mammal Program; KSW, Kamogawa Sea World; GA, Genoa Aquarium.

b Urine samples were collected from females and semen samples from males.

${ }^{\mathrm{c}}$ Data that the animal contributed to the study: EC, urinary oestrogen conjugate; ES, oestrous synchronisation; LH, luteinizing hormone; UP, urinary progestagen metabolites.

${ }^{\mathrm{d}}$ Ejac, number of ejaculates collected and used during the study.

salt-water enclosure (ambient temperature $24-28^{\circ} \mathrm{C}$ ) with three other dolphins of mixed age and sex.

All animals used for Al trials were held without access to males for a minimum of 1 month prior to the procedures. Three of the females (females 9, 10 \& 11) used for Al trials were located at Kamogawa Sea World, Chiba, Japan. These three females were housed together in a $945 \mathrm{~m}^{3}$ enclosure with processed natural saltwater (ambient temperature $17-28^{\circ} \mathrm{C}$ ) with one other adult female and two male and two female juvenile animals. Two adult males (males 3 and 4) located at Kamogawa Sea World were semen donors for the Als performed at that facility. They were housed separately in a $500 \mathrm{~m}^{3}$ pool with a mixed breeding group of dolphins. Seven females (females $2-5,7,8$ and 13) were located at SeaWorld California (SWC), housed in an outdoor pool containing $850 \mathrm{~m}^{3}$ of natural processed salt water (ambient temperature $18^{\circ} \mathrm{C}$ ) during the study. The male (male 1) who donated the semen for the Als at SWC and female 6 were located at the US Navy Marine Mammal Program in San Diego,
California, USA. They were housed in various natural saltwater interconnected enclosures ranging in size from 300 to $600 \mathrm{~m}^{3}$ (ambient temperature $13-21^{\circ} \mathrm{C}$ ). The remaining female (female 12) was located at the Acquario di Genova (Genova, Italy) in a $1700 \mathrm{~m}^{3}$ outdoor facility that relies on natural filtered salt water (ambient temperature 14 to $26^{\circ} \mathrm{C}$ ). Semen used for this animal was from male 2 housed at SWC as previously described. Animals located in the US and Italy were fed a diet of frozenthawed whole fish (herring (Clupea harengus) capelin (Mallotus villosus) and Columbia river smelt (Thaleichthys pacificus)). In addition, the animal in Italy was also fed squid (Loligo vulgaris). The animals in Japan were fed chub mackerel (Scomber japonicus) and Arabesque greenling (Pleurogrammus azonus). All animals were fed at approximately $4-5 \%$ of their body weight per day.

\section{Ethics of experimentation}

All samples were collected using routine husbandry training and were obtained from unrestrained animals. All 
procedures described within were reviewed and approved by the SeaWorld Incorporated Institutional Animal Care and Use Committee, and were performed in accordance with the Animal Welfare Act for the care of Marine Mammals.

\section{Endocrine monitoring}

Urine samples were collected from unrestrained animals as previously described (Lenzi 2000). Urine samples from female 1 were collected daily for 92 days for endocrine monitoring (EM) of estrous cycles. All other urine samples analyzed were associated with estrous synchronisation attempts or Al trials (Table 1). Samples were stored in duplicate at $-70^{\circ} \mathrm{C}$ until analysis. Non-extracted urine samples were analyzed by enzyme immunoassay (EIA) for total immunoreactive levels of urinary progestins (UP), EC and LH. During the initial part of the study (2002) urine samples were collected twice daily for EM, estrous synchronisation (ES) or Al trials. However, during the latter part of the study (2003-2004), urine samples were collected three times a day as ovulation approached (Table 1). Urinary EC and LH were determined at the facility where the animal scheduled for Al was housed using our mobile endocrine laboratory (Steinman et al. 2003) and UP was determined retrospectively at the central laboratory (CRC, Front Royal, VA, USA).

Determination of total estrous cycle length (TCL) was based on either the interval between the beginning of successive LH peaks, or successive EC peaks. For the study, $\mathrm{LH}$ and $\mathrm{EC}$ peaks were defined as the maximum concentration for the respective hormones during the estrous period. In addition, intra-estrous cycle endocrine components were determined as follows: length of the luteal phase (UP concentrations $>0.56 \mathrm{ng} / \mathrm{mg} \mathrm{Cr}$ for 2 consecutive days); follicular phase (EC concentrations $>0.93 \mathrm{ng} / \mathrm{ml} \mathrm{Cr}$ for two consecutive days); start of follicular phase to peak EC, and peak EC to peak $\mathrm{LH}$ were also determined. The preovulatory rise in EC concentrations was subjectively defined as values $>2 \mathrm{ng} / \mathrm{mg} \mathrm{Cr}$ until the $\mathrm{LH}$ peak. The time from the beginning of the $\mathrm{LH}$ surge to peak LH and the total length of the LH surge were determined in animals with thrice daily sample collection. The beginning of the surge was defined as any value greater than 2 S.D. above baseline for that animal that was followed by the LH peak. If the LH surge began or ended between two sample periods, we subjectively assigned the beginning of the surge as occurring midway between the two samples. A 'normal' estrous cycle was determined by combining the mean values of all dolphins for all of the above-mentioned intervals.

Endocrine data were compared with the ultrasonographically estimated ovulation point (the midpoint between exams where the follicle is present in one and disappears in the next) to define the interval between the $\mathrm{EC}$ and $\mathrm{LH}$ peak and ovulation.

\section{Cr assay}

Urine samples were analyzed for $\mathrm{Cr}$ to account for varying concentrations of urine as described previously (Taussky 1954). Concentrations of urinary hormones and metabolites were expressed as mass of hormone per $\mathrm{mg} \mathrm{Cr}$ excreted.

\section{Assay for UP}

UP were measured by single antibody, direct enzyme immunoassay as described previously (Graham et al. 2001). Briefly, neat urine samples $(0.025-0.01 \mathrm{ml})$ and standards (range $200-0.79 \mathrm{pg} /$ well; Sigma-Aldrich, St Louis, MO, USA) were added in duplicate to microtiter plates (Maxisorp, Nalge Nunc, Rochester, NY, USA) coated with a progestin antisera (polyclonal CL425, 1:10 000; C Munro, UC Davis, CA, USA ). After 2-h room temperature incubation with enzyme conjugate (progesterone horseradish peroxidase, 1:40000; C Munro), $0.1 \mathrm{ml}$ substrate (azino-bis-3-ethyl benzthiazoline-6-sulfonic acid in citrate buffer; Sigma-Aldrich) was added and incubated for an additional hour. Plates were read at $405 \mathrm{~nm}$ (reference $540 \mathrm{~nm}$ ) in a microplate reader (MRX, Dynex Technologies, Chantilly, VA, USA). Intra-assay variation was $<10 \%$ and inter-assay variations were $9.1 \%$ and $15.7 \%$, at $30 \%$ and $70 \%$ binding, respectively $(n=75)$. Serial dilutions of bottlenose dolphin urine yielded displacement curves that were similar to the standard curve $\left(R^{2}=0.99\right)$. The mean recovery of progesterone added to a pool of bottlenose dolphin urine was $84.3 \pm 3.8 \%(y=0.89 x$ $-0.25, R^{2}=0.99$ ). Immunoassay of fractions separated by reverse-phase HPLC analysis revealed three immunoreactive peaks at fractions $21-25$ and fraction 46 which were unidentified and at fractions 67-71 that co-eluted with progesterone.

\section{EIA assay for EC}

Urinary estrogen conjugates were measured by single antibody, direct enzyme immunoassay as previously described (Robeck et al. 2004). Briefly, neat urine samples (0.025$0.0025 \mathrm{ml}$ ) and standards (range $200-0.79 \mathrm{pg} /$ well; SigmaAldrich) were added to a microtiter plate coated with E1G antisera, and an enzyme conjugate was added to all wells. After incubation, $0.1 \mathrm{ml}$ of substrate (tetramethylbenzidine in phosphate citrate buffer; Sigma-Aldrich.) was added to all wells and incubated at room temperature for $30 \mathrm{~min}$. Finally, $0.05 \mathrm{ml} 0.6 \mathrm{M} \mathrm{H}_{2} \mathrm{SO}_{4}$ were added. Intraassay variation was $<10 \%$ and inter-assay variation was $9.7 \%$ and $14.5 \%$ at $30 \%$ and $70 \%$ binding, respectively $(n=66)$. Serial dilutions of bottlenose dolphin urine yielded displacement curves that were similar to the standard curve $\left(R^{2}=0.99\right)$. The mean recovery of estrone glucuronide added to a pool of bottlenose dolphin urine was $126.9 \pm 22.6 \% \quad\left(y=0.86 x+1.07, R^{2}=0.99\right)$. Immunoassay of fractions separated by reverse-phase HPLC analysis revealed one major immunoreactive peak (fractions $19-22,16 \%$ of total) that co-eluted with estrone-3-sulfate. 


\section{LH EIA}

Urinary LH was measured by single antibody, direct enzyme immunoassay modified from the double antibody EIA developed by Graham et al. (2002). Briefly, antisera (LH 518-B7, 1:400 000; J Roser, UC Davis, CA, USA) was added to 96 -well flat-bottom microtiter plates and incubated at $4{ }^{\circ} \mathrm{C}$ overnight. Neat urine samples (0.05$0.0005 \mathrm{ml}$ ) and standards (range $500-1.95 \mathrm{pg} /$ well) were added to wells in duplicate and the plate incubated at $37^{\circ}$ $\mathrm{C}$ for $3 \mathrm{~h}$. Biotinylated $\mathrm{LH}(1: 100000,0.1 \mathrm{ml})$ was then added to all wells and the plate was incubated for $30 \mathrm{~min}$ at $37^{\circ} \mathrm{C}$. After incubation, plates were washed and then $0.2 \mathrm{ml}$ streptavidin peroxidase added for an additional $30 \mathrm{~min}$ incubation. Substrate $(0.2 \mathrm{ml}$ tetramethyl benzidine in phosphate citrate buffer) was added, incubated for $40 \mathrm{~min}$, and the reaction was stopped with $0.05 \mathrm{ml}$ of $0.6 \mathrm{M} \mathrm{H}_{2} \mathrm{SO}_{4}$. Intra-assay variation was $<10 \%$ and interassay variation was $12.2 \%$ and $15.8 \%$ at $30 \%$ and $60 \%$ binding, respectively $(n=118)$. Serial dilutions of bottlenose dolphin urine yielded displacement curves that were similar to the standard curve $\left(R^{2}=0.99\right)$. The mean recovery of $\mathrm{LH}$ added to a pool of bottlenose dolphin urine was $53.0 \pm 15.7 \%\left(y=1.52 x-0.74, R^{2}=0.99\right)$.

\section{Synchronisation of ovulation using progesterone analog for $A I$}

To evaluate the effects of altrenogest as a synchronisation tool for use with artificial insemination, animals were placed on $0.044 \mathrm{mg} \mathrm{kg}^{-1}$ p.o. altrenogest (Regu-Mate, Intervet Inc., Millsboro, DE, USA) from 27-77 days. A total of 27 treatments were administered to 12 female dolphins (Fig. 1). The drug was administered by injecting directly into the coelomic cavity of a herring just prior to feeding. Immunoreactive UP, EC and LH were determined from urine samples collected daily during altrenogest treatment and at least twice daily after its cessation.

\section{Ultrasonography}

Ultrasonography was used to detail follicular activity following altrenogest treatment and to confirm pregnancy. Ultrasonographic examinations were performed using an Aloka 900 machine (Corimetrics Medical, Charlotte, NC, USA) and a $3.5 \mathrm{MHz}$ transducer (wide footprint convex linear probe) or a EUB 405/Spazio Hitachi with a $3.5 \mathrm{MHz}$ convex linear transducer (Acquario di Genova, Genova, Italy). Animals were examined once on day 0 and day 10 post-altrenogest, then daily to thrice daily from day 11 to ovulation. For examinations, the animals were trained to station in lateral recumbency adjacent to the edge of the pool. The ovaries were located transabdominally using a previously described technique (Brook 2000). Follicular size was determined by measuring its largest diameter, utilizing the anechoic margins as the border. Follicular circumference was calculated by software associated with the ultrasound machine or by determining the diameter in two planes and using the following formula ( $\& \mathrm{~b}=$ radius):

$$
C=2 \pi \sqrt{\frac{\left(a^{2}+b^{2}\right)}{2}}
$$

Ovulation was determined to have occurred when the follicle was not detectable in a subsequent exam. The time of ovulation was defined as the median time between the prior exam and the exam when the follicle could not be located. This interval between exams was a maximum of $12 \mathrm{~h}$ for twice daily and $8 \mathrm{~h}$ for three times daily examination.

\section{Semen collection and processing}

Ejaculates were collected from male $1(n=2)$, male 2 $(n=1)$ and male $4(n=6)$ and cryopreserved for later use. Ejaculates from male $3(n=4)$ were extended and

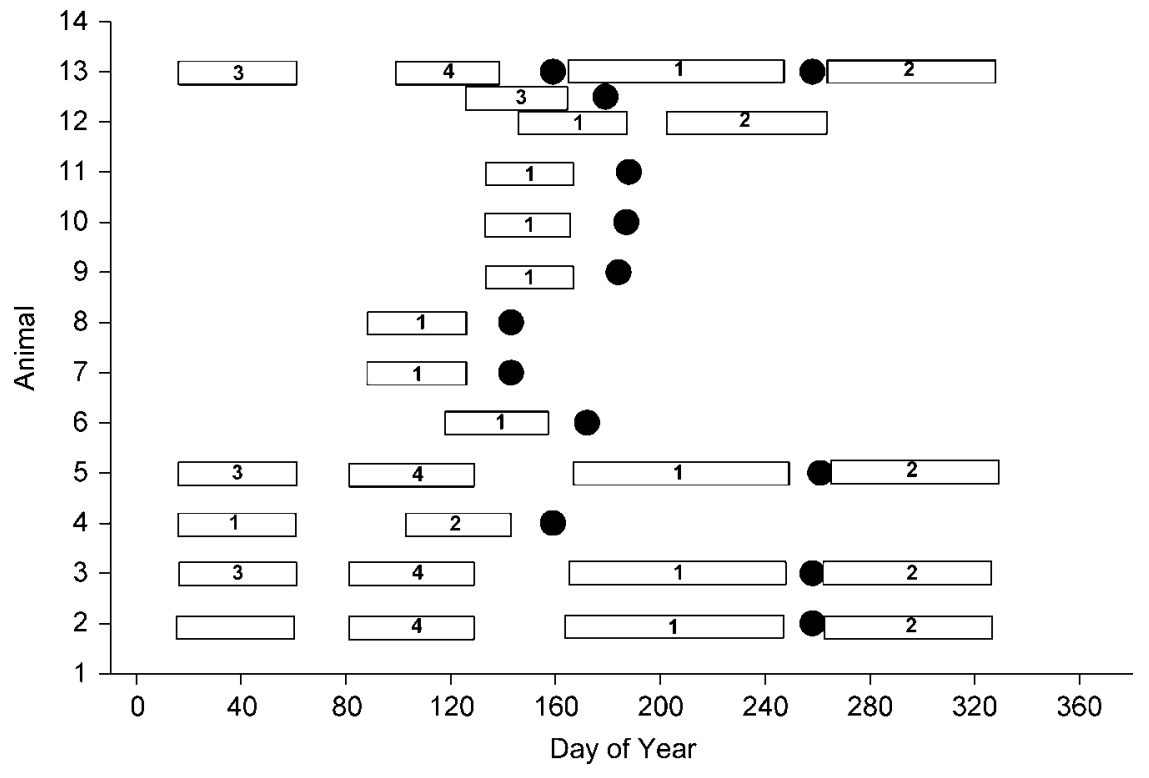

Figure 1 Yearly schedule of altrenogest administration. The animal numbers on the graph corresponds to the animal numbers in Table 1 and in the text. Animal 12 and 12.5 correspond to animal 12 as described in the Table 1. In this animal, altrenogest was administered during two consecutive years. Note the 4 altrenogest treatments given to 4 animals (females 2, 3, 5 and 13) during one year. Normal ovulations (black circle) only occurred from May to September. 
liquid stored for use during the Al trials (Table 1). All males were trained for unrestrained ejaculation as previously described (Keller 1986, Robeck \& O'Brien 2004).

Ejaculate concentration, volume, sperm motility, and viability (plasma membrane integrity) were determined using standardized techniques (Robeck \& O'Brien 2004). The percentages of motile sperm were subjectively determined to the nearest $5 \%$ by analyzing $4-5$ fields of undiluted (male 4) or diluted spermatozoa $\left(35^{\circ} \mathrm{C}, 1\right.$ unit spermatozoa:25 units Biladyl Fraction A (Minitube of America, Verona, WI, USA); Tris (1210 gm), citric acid $(690 \mathrm{gm})$, fructose $(5 \mathrm{gm})$ and $20 \%$ egg yolk $(\mathrm{v} / \mathrm{v})$ per $500 \mathrm{ml}$ ) with antibiotics (Tylosin $\left(0.5 \mathrm{mg} \mathrm{ml}^{-1}\right)$, Gentamy$\operatorname{cin}\left(2.5 \mathrm{mg} \mathrm{ml}^{-1}\right)$, Lincomycin $\left(1.5 \mathrm{mg} \mathrm{ml}^{-1}\right)$ and spectinomycin $\left.\left(3 \mathrm{mg} \mathrm{ml}^{-1}\right)\right)$ using bright field optics (x400, Olympus, Tokyo, Japan). Total progressive motility (PM) and kinetic rating (KR, $0-5$ scale: 0, no movement; 5, rapid forward progressive movement) were subjectively determined. A sperm motility index (SMI; total progressive motility $\times$ kinetic rating) was developed for comparisons of sperm quality between fresh and post cryopreserved or liquid stored spermatozoa.

For assessment of viability, $10 \mu \mathrm{l}$ semen was mixed with $40 \mu$ l live dead exclusion stain (eosin-nigrosin, IMV International Corp., Maple Grove, MN, USA) for 30 s. For each ejaculate an air-dried smear was used to evaluate 200 spermatozoa using bright field optics $(\times 1000)$. Spermatozoa were then placed into one of two groups based on stain uptake by the sperm head: live (no stain uptake) and dead (partial or complete stain uptake).

\section{Processing of semen for liquid storage}

Liquid stored semen was only used from male 3 during the insemination attempts in Japan. Ejaculates were diluted 1:2 (semen:diluent, v/v) over 5 min with Biladyl Fraction A. Biladyl was chosen due to its ease of preparation and preliminary studies that demonstrated its ability to maintain high levels of bottlenose dolphin sperm motility during storage for $24 \mathrm{~h}$ at $4{ }^{\circ} \mathrm{C}$ (T Robeck, unpublished). Sperm suspension $(10 \mathrm{ml})$ was kept at $21^{\circ} \mathrm{C}$ and used within $4 \mathrm{~h}$ for Al. The second half was cooled to $5^{\circ} \mathrm{C}$ from $21^{\circ} \mathrm{C}$ over $1 \mathrm{~h}\left(-0.27^{\circ} \mathrm{C} \mathrm{min}^{-1}\right)$ and used for $\mathrm{Al}$ within $24 \mathrm{~h}$. After storage and prior to each insemination, a 15-ul portion was removed from each sample, warmed to $35^{\circ} \mathrm{C}$ and re-evaluated (PM and $\mathrm{KR}$ ).

\section{Processing of semen for frozen storage}

Semen cryopreservation of samples occurred over a $12 \mathrm{yr}$ period, and as methods improved changes in freezing protocols were incorporated. Thus, three different methods were used to cryopreserve spermatozoa that were used during the $\mathrm{Al}$ attempts.

\section{Method 1}

Semen from male 4 was pelleted, based on a modified procedure first described by Seager et al. (1981). Sperm samples were diluted 1:1 (v/v) with egg yolk citrate cryodiluent (EYC; $2.9 \%$ Na citrate, 20\% egg yolk (v/v) and $8 \%$ glycerol $(\mathrm{v} / \mathrm{v}))$ and cooled from $21^{\circ} \mathrm{C}$ to $5{ }^{\circ} \mathrm{C}$ over $1 \mathrm{~h}$ $\left(-0.27^{\circ} \mathrm{C} / \mathrm{min}\right)$. At $5^{\circ} \mathrm{C}$ the sample was further diluted $(1: 1)$ over $5 \mathrm{~min}$ with EYC for a final glycerol concentration of $6 \%$. After incubation at $5{ }^{\circ} \mathrm{C}$ for $2 \mathrm{~h}$, the sperm suspension was frozen as approximately $0.2 \mathrm{ml}$ pellets on dry ice for $5 \mathrm{~min}$ prior to plunging in liquid nitrogen.

\section{Method 2}

Sperm samples from male 1 were diluted with Biladyl Fraction A $(2: 1$, semen: diluent) slowly over $5 \mathrm{~min}$. The sperm suspension was cooled from $21^{\circ} \mathrm{C}$ to $5^{\circ} \mathrm{C}$ over $1 \mathrm{~h}$ $\left(-0.27^{\circ} \mathrm{C} \min ^{-1}\right)$. Once at $5^{\circ} \mathrm{C}$, the sperm suspension was placed into an ice water bath $\left(2{ }^{\circ} \mathrm{C}\right.$ ) for $1 \mathrm{~h}$ (cooling rate: $\left.-0.6{ }^{\circ} \mathrm{C} \min ^{-1}\right)$, then diluted $1: 1(\mathrm{v} / \mathrm{v})$ slowly with Biladyl Fraction B (Fraction A with 14\% glycerol (7\% final glycerol concentration)). The sperm suspension was transferred to $0.5 \mathrm{ml}$ straws (IMV International), sealed and frozen in liquid nitrogen vapor at a distance of $4.5 \mathrm{~cm}$ above the vapor $\left(-12{ }^{\circ} \mathrm{C} \mathrm{min}^{-1}\right)$ for $10 \mathrm{~min}$ then plunged into liquid nitrogen.

\section{Method 3}

Sperm samples from male 2 were frozen by the method previously described by Robeck \& O'Brien (2004). Semen was diluted 1:1 (v/v) with a TES-TRIS yolk buffer (TYB) (Refrigeration Media, $320 \mathrm{mosm} \mathrm{kg}^{-1}$, pH 7.2; Irvine Scientific, Santa Ana, CA, USA) without glycerol slowly over $5 \mathrm{~min}$. The sperm suspension was cooled from 21 to $5{ }^{\circ} \mathrm{C}$ over $1 \mathrm{~h}\left(-0.27^{\circ} \mathrm{C} \mathrm{min}^{-1}\right)$. Once at $5^{\circ} \mathrm{C}$ the sperm suspension was diluted 1:1 with TYB containing $6 \%$ glycerol (Freezing Media, Irvine Scientific, modified from $12 \%$ by dilution with Refrigeration Media; 3\% final concentration) and loaded into $0.5 \mathrm{ml}$ straws. Straws were frozen using a programmable freezer (Minidigicool, IMV International) as follows: 5 to $-80{ }^{\circ} \mathrm{C}$ at $-100{ }^{\circ} \mathrm{C} \mathrm{min}^{-1}$; -80 to $-140^{\circ} \mathrm{C}$ at $-200^{\circ} \mathrm{C} \mathrm{min}^{-1}$.

Semen was thawed using methods tailored for the pellet or straw freezing method, respectively. For pellets, $4 \times 0.2 \mathrm{ml}$ frozen pellets were added directly to $0.5 \mathrm{ml}$ EYC pre-warmed to $35^{\circ} \mathrm{C}$. The sperm suspension was vigorously shaken in a $35^{\circ} \mathrm{C}$ water bath for $1 \mathrm{~min}$. The straws from methods 1 and 2 were thawed by plunging directly into a $35^{\circ} \mathrm{C}$ water bath and shaken vigorously for $1 \mathrm{~min}$ $\left(8.3^{\circ} \mathrm{C} \mathrm{s}^{-1}\right)$. Straws were combined and then either diluted $(1: 1)$ over $5 \mathrm{~min}$ with Androhep Enduraguard (Minitube of America, $\mathrm{pH}$ adjusted to 7.2 , warmed to $35^{\circ} \mathrm{C}$ ) prewarmed to $35^{\circ} \mathrm{C}$ or used undiluted. Thawed sperm suspensions from all methods were evaluated for motility parameters (PM, KR) and then stored at $21^{\circ} \mathrm{C}$ until the inseminations.

\section{AI}

The first two inseminations (females 7 and 8) were based on the presence of a POF and/or the detection of peak 
urinary EC. Females 9-11 were inseminated based solely on follicle growth. Once the follicle subjectively appeared to be of preovulatory size $(>2.0 \mathrm{~cm})$, the animals were inseminated every $12 \mathrm{~h}$ until ovulation was confirmed by ultrasonography. Inseminations 6-8 (females 12 and 13) were timed to occur after the detection of the pre-ovulatory $\mathrm{LH}$ surge in the urine.

For each procedure, the use of liquid or frozen-thawed semen was based on availability. If cryopreserved semen was unavailable, fresh semen was collected 3 to $4 \mathrm{~h}$ prior to the insemination. One hour before the procedures, all females were pre-medicated with diazepam $(0.1-0.2 \mathrm{mg} / \mathrm{kg}$; Abbott Lab, Chicago IL, USA). The animals were removed from the water and placed in lateral recumbency on $10.2 \mathrm{~cm}$ thick closed cell foam pads. All animals were kept wet during the procedure and monitored for respiration rate. Inseminations were performed with a variety of flexible endoscopes $(9-11 \mathrm{~mm}$ in diameter and $190-250 \mathrm{~cm}$ long) depending on endoscope availability at each facility. For the procedures, the endoscope was advanced into the cranial vagina. The vagina was insufflated with air to visualize the spermathecal fold and the cervical opening beyond (Robeck et al. 1994). A modified bullet tipped catheter $(400 \mathrm{~cm}, 2.2 \mathrm{~mm}$ external diameter [6 French] Cook Vet Supplies, QLD, Australia) was placed in the working channel of the endoscope and used as a stylet to assist directing the endoscope into the cervix. Once in the uterus, the inseminations were initially performed at the uterine body or partially into each horn by the advancement of the catheter and deposition of half the semen dose in each horn (inseminations 1-5; females $7-11)$. The last three inseminations $(6-8)$ were placed high in the ipsilateral horn to the preovulatory follicle (females 12 to 13 ).

\section{Statistics}

Hormone and sperm quality data were analyzed by analysis of variance and means compared using Newman-Keuls multiple comparisons and Mann-Whitney $U$ tests (SigmaStat, Version 2.0. SPSS Inc., San Rafael, CA, USA). Data are presented as Mean \pm S.D.

\section{Results}

\section{Endocrine monitoring}

Hormone (EC, LH and UP) profiles during the peri-ovulatory interval of three natural cycles and nine post altrenogest cycles were monitored during the study interval. One of these cycles, as assessed by UP and ultrasound, did not exhibit a post-ovulation luteal phase. In addition, endocrine data were evaluated during and after 14 altrenogest treatments where ovulation post-treatment did not occur. For the natural cycles, female 12 had one normal cycle prior to being placed on altrenogest for Al trial, and female 1 had two successive natural cycles with the second cycle resulting in pregnancy (Fig. 1). Female 1 was the only female that had two successive natural (non-synchronized) ovulations during the sampling period. Based on the three natural cycles, the interval between successive peak EC and LH was 35.5 days and 36.0 days, respectively, and the mean time between peak EC to peak LH was $4.0 \pm 6.9 \mathrm{~h}$ (Fig. 2).

For natural and synchronized estrous cycles, the mean interval from peak EC to $\mathrm{LH}$ was $7.5 \pm 3.8 \mathrm{~h}$. The lengths of the follicular and luteal phases were $8.1 \pm 3.0$ days ( $n=10$, range $4-14$ days) and $19.3 \pm 2.8$ days $(n=6$, range 16-23 days), respectively. The preovulatory EC rise (i.e. the interval between when EC exceeded $2.0 \mathrm{ng} / \mathrm{mg} \mathrm{Cr}$ until the pre-ovulatory EC peak) was $2.4 \pm 1.8$ days $(n=10$, range $0-5$ days). The interval between peak EC and peak $\mathrm{LH}$ was $7.5 \pm 10.6 \mathrm{~h}(n=12$, range -0.3 to $24 \mathrm{~h}$ ). The time from the onset of $\mathrm{LH}$ surge to peak $\mathrm{LH}$ was $9.4 \pm 3.1 \mathrm{~h}(n=6$, range $5.5-12.5 \mathrm{~h})$. The LH surge duration was $20.3 \pm 5.1 \mathrm{~h}(n=6$, range $12-25 \mathrm{~h})$. Peak EC and $\mathrm{LH}$ concentrations were $5.4 \pm 3.8 \mathrm{ng} / \mathrm{mg} \mathrm{Cr}(n=12$, range $2.1-13.7 \mathrm{ng} / \mathrm{mg} \mathrm{Cr}$ ) and $70.9 \pm 115.7 \mathrm{ng} / \mathrm{mg} \mathrm{Cr}$ $(n=12$, range $10.2-429 \mathrm{ng} / \mathrm{mg} \mathrm{Cr})$, respectively. The interval between peak $\mathrm{LH}$ and the first discernable postovulatory increase in UP was $2.1 \pm 0.6$ days $(n=9$, range 1-3 days). Mean estrous cycle phase durations, as described above, were used to develop a composite dolphin estrous cycle (Fig. 3).

\section{Estrous synchronisation}

Of the 27 altrenogest treatments, $13(48 \%)$ resulted in subsequent ovulation. For the animals that responded to synchronisation, the mean time from the end of altrenogest treatment to the beginning of the follicular phase, the $\mathrm{LH}$ surge and ovulation were $11.6 \pm 3.8$ days $(n=8$, range $7-17$ days), $18.7 \pm 3.1$ days $(n=9$, range $14-23)$ and $20.8 \pm 3.2$ days $(n=13$, range $15-25)$, respectively. In females that did not ovulate, the post altrenogest increase in EC concentrations began $10.9 \pm 3.1$ days $(n=14$, range $7-14.5$ days) post altrenogest (Fig. 4). The interval from the end of altrenogest administration to first EC rise above baseline was similar $(P>0.05)$ between animals that ovulated and those that did not. Female 12 was placed on altrenogest twice during a three month period in 2003 (Fig. 1). She did not ovulate during the first attempt (July), but ovulated after the second attempt (September). Despite what appeared ultrasonographically and endocrinologically to be a normal ovulation, a corpus luteum $(\mathrm{CL})$ could not be detected ultrasonographically 10 days post ovulation and circulating progesterone concentrations remained basal. Following a natural ovulation, female 12 was again placed on altrenogest and subsequently ovulated. Despite being treated with altrenogest shortly after her natural ovulation, she had a normal luteal phase of 20 days (Fig. 2).

Four females (females 2, 3, 5 and 13) were placed on altrenogest on four separate occasions. Their initial 77 day altrenogest treatment interval was used to achieve 


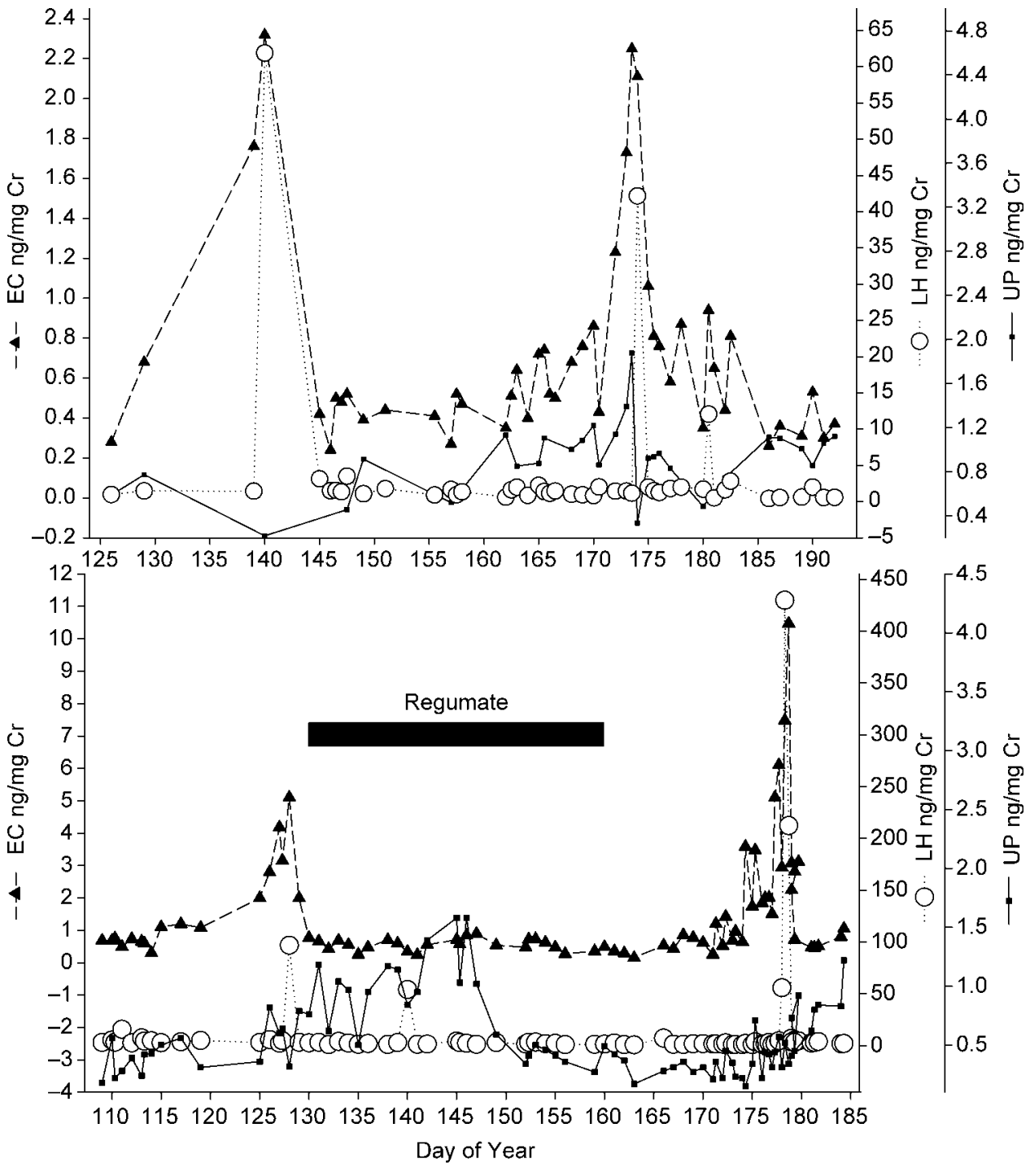

Figure 2 Three natural ovulations in females 1 (top panel) and 12 (bottom panel) characterized by urinary concentrations of $\mathrm{LH}, \mathrm{EC}$ and UP. The black bar represents altrenogest administration in female 12. Note that UP concentrations continue to increase and are detected for 20 days post-ovulation, despite administration of altrenogest. Note the obvious $\mathrm{LH}$ surges detected during $12 \mathrm{~h}$ urine sampling periods for female 1 and during the second $\mathrm{LH}$ surge of female 12. The smaller LH surge of the first cycle for female 12 is reflective of once daily urine sampling. both contraception and estrous synchronisation; all 4 females ovulated post-altrenogest treatment (Fig. 1). However, during the three subsequent treatments ( $n=12$ treatments), only female 13 ovulated, and this occurred after the fourth treatment (Fig. 1). These failed attempts at repeated estrous synchronisation accounted for 11 of 14 regumate treatments that did not result in ovulation.

\section{Ultrasonographic evaluation of ovaries}

Dominant follicles (present less than $12 \mathrm{~h}$ prior to ovulation) were observed during 11 estrous cycles: eight during $\mathrm{Al}$ attempts and three during monitoring of natural $(n=1)$ or synchronized $(n=2)$ estrous cycles. Secondary follicles on the ipsilateral $(n=2)$ and contralateral ovary $(n=4)$ were observed in $54 \%$ of the examinations. Although these follicles were not measured in every exam, they were $1 \mathrm{~cm}$ or less in diameter and had regressed at the time of ovulation. The earliest time that a dominant follicle was detected was 10.5 days prior to ovulation; the follicle diameter exceeded $1 \mathrm{~cm}$ in all instances. The mean time and circumference of a dominate follicle when it was first observed prior to ovulation was $5.5 \pm 2.7$ days and $4.2 \pm 0.9 \mathrm{~cm}$, respectively. The mean daily follicular growth rate in circumference was $0.47 \pm 0.2 \mathrm{~cm}$ per day. The maximum circumference and diameter of a preovulatory follicle were $6.5 \pm 1.5 \mathrm{~cm}$ (range, $4.23-9.6)$ and $2.1 \pm 0.5 \mathrm{~cm}(n=11$, range $1.7-$ $3.1 \mathrm{~cm})$, respectively. The preovulatory follicle consistently became turgid and round prior to ovulation and was located on the left ovary $82 \%$ of the time (Fig. 5). On several occasions the borders of the follicle appeared to thicken, however this was not consistently noted and did not correlate with impending ovulation. Maximum size of the preovulatory follicle had no significant correlation with peak urinary estrogen concentrations $\left(\mathrm{R}^{2}=0.27, \quad P>0.05\right)$, follicle growth rate $\left(\mathrm{R}^{2}=0.65\right.$, $P>0.05)$ or animal size $\left(R^{2}=0.11, P>0.05\right)$. The time of ovulation, as determined by ultrasonography, occurred 


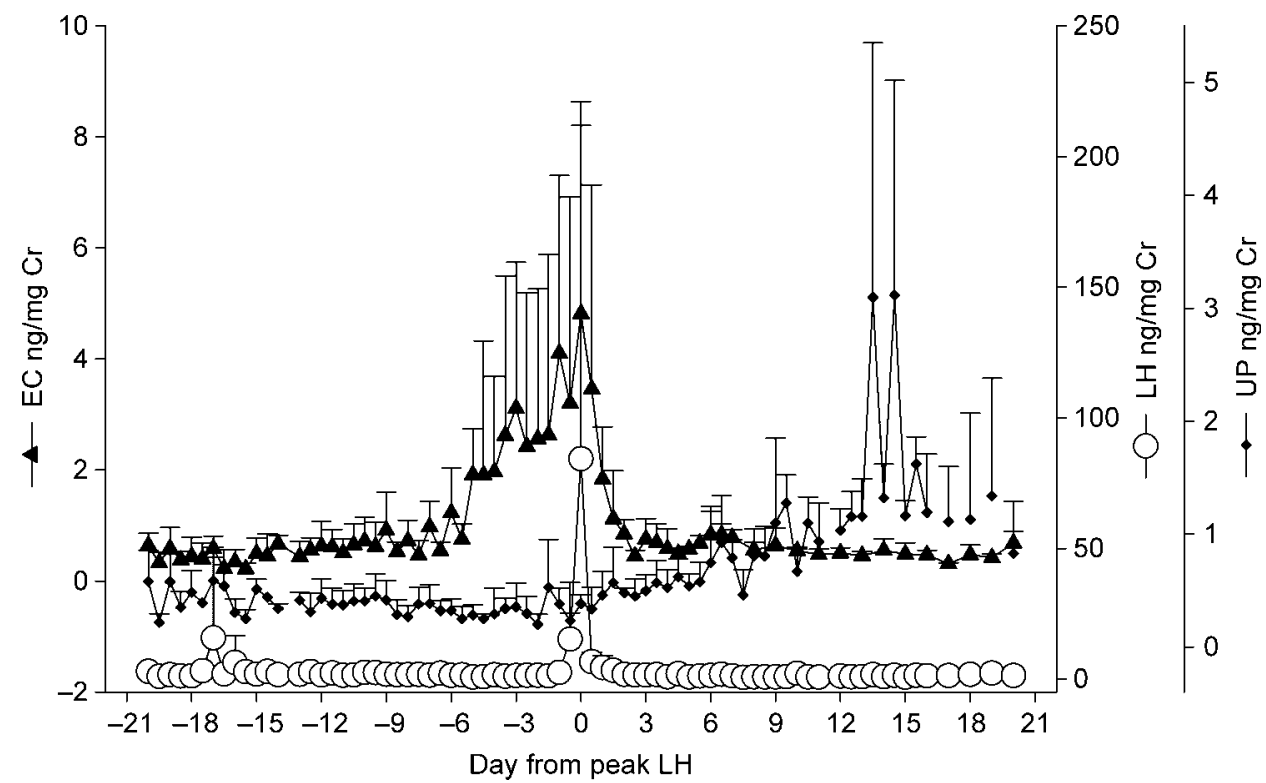

Figure 3 Mean values of bottlenose dolphin estrous cycle components, including urinary concentrations of LH $(n=12)$, EC $(n=12)$ and UP $(n=9)$. Note the LH peak occurs approximately the same time $(8 \mathrm{~h}$ after $)$ as the peak EC.

$26.8 \pm 7.1 \mathrm{~h}, 32.1 \pm 8.9 \mathrm{~h}$ and $24.3 \pm 7.0 \mathrm{~h}$ after peak EC, LH surge onset and peak $\mathrm{LH}$, respectively (Fig. 6). All but one animal sonogrammed after ovulation (within $12 \mathrm{~h})$ consistently had a 'donut shaped' structure consisting of a hyperechoic ring around a small anechoic center (Fig. 5). Female 7 was examined during ovulation with the follicle contracting into a stellate appearance (Fig. 5).
The stellate structure disappeared within $1 \mathrm{~h}$, leaving a 'donut shaped' echosignature. The longevity of the 'donut shaped' structure was not determined because once ovulation had been confirmed the animal was not examined again for $1 \mathrm{wk}$. The earliest point that the $\mathrm{CL}$ could be detected was not determined, due to the infrequency of examinations. A cavitated hypoechoic $\mathrm{CL}$ was

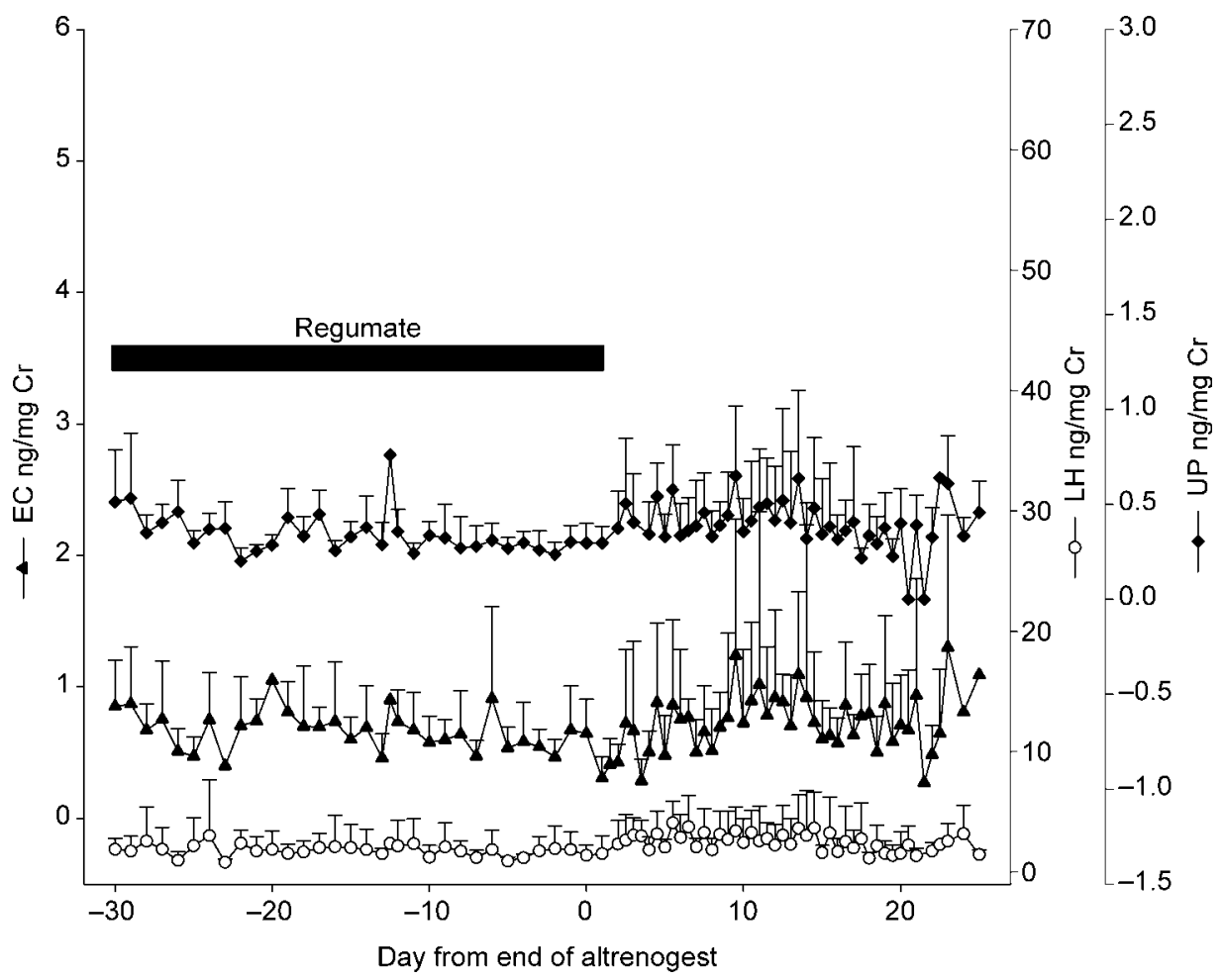

Figure 4 Mean LH, EC and UP concentrations from animals that did not ovulate after altrenogest treatment (black bar). Please note the increase in estrogen concentrations approximately $11 \mathrm{~d}$ after treatment ended. 

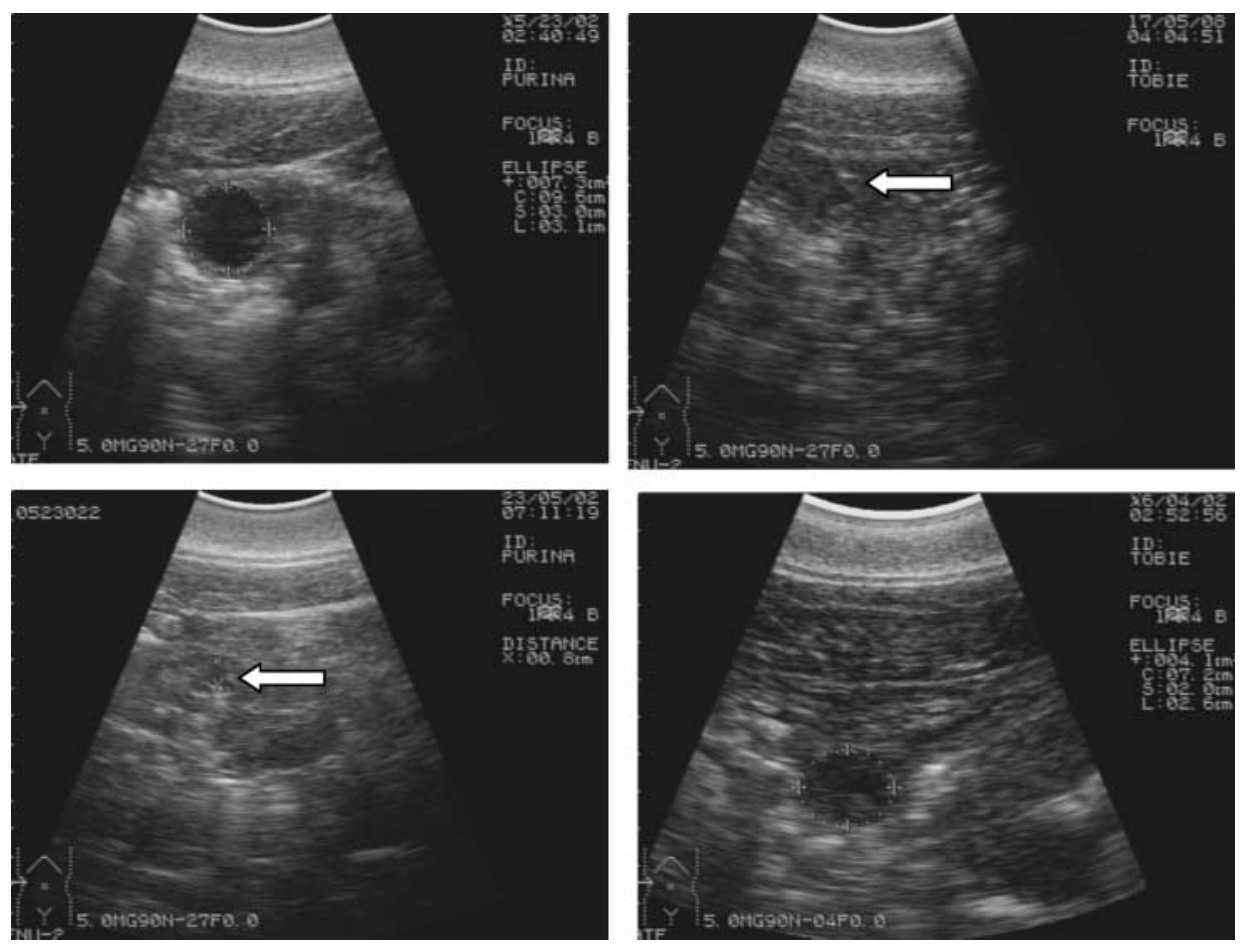

Figure 5 Bottlenose dolphin ovarian ultrasonographic images. A round, turgid preovulatory follicle (outlined by calipers, top left panel); the stellate (white arrow) appearance of an ovulating follicle (top right panel); the post-ovulatory 'donut shaped' signature (white arrow, bottom left panel); a corpus luteum (outlined by calipers) of pregnancy with a central fluid filled (anechoic) cavitation (bottom right panel).

observed during the early post-ovulatory interval in females 7, 8 and 12, which later appeared as a homogenous hypoechoic structure (Fig. 5). All non-pregnant animals had a homogenous CL. Fluid in the uterus was detected as early as $5 \mathrm{wk}$ post Al. However, since each facility had differing access to an ultrasound machine and varying technical skills at interpreting the images, no conclusion could be made concerning the earliest time that pregnancy could be diagnosed. Overall, all pregnancies were confirmed by ultrasonography between $5 \mathrm{wk}$ and 3 months post Al (Fig. 5).

\section{Ejaculate characteristics in undiluted, liquid-stored, post-transport and post-thawed sperm}

Characteristics of 13 ejaculates collected from four males are shown in Table 2. Overall, ejaculates were of high quality with total percent sperm motility and viability $>84 \%$. During liquid storage for up to $24 \mathrm{~h}$ post-collection, samples retained $94.6 \%$ of the SMI found in undiluted ejaculate (Table 2). The longest a sample was stored before being used for an insemination was $24 \mathrm{~h}$, and this insemination in female 9 resulted in a pregnancy.

Motility parameters of dolphin spermatozoa frozen in straws either over liquid nitrogen (method 2: PM $56 \pm 12.1 \%$ ) or using a programmable freezer (method 3; PM $61.8 \pm 3.2 \%$ ) maintained a higher post-thaw percent SMI than straws frozen with pellets on dry ice (method 1 : PM $25.7 \pm 12.4 \%$ ). However, statistical comparisons could not be made between the freezing methods because samples were frozen years apart, with different diluents and different freezing rates (Table 2).
AI

Al was performed in seven animals during eight estrous cycles from May 2002 to June 2004 (Table 3). The first two animals were inseminated based on peak EC and follicle size and appearance (turgid round follicle, Fig. 5). The first animal (female 7) was inseminated as ovulation was occurring and the second (female 8) was inseminated within $4 \mathrm{~h}$ post-ovulation. Both animals were only inseminated once with frozen-thawed sperm and on both occasions they were inseminated directly into the uterus (Table 3). Both animals subjectively exhibited behavioral estrous 24 to $12 \mathrm{~h}$ prior to ovulation. Characteristics of behavioral estrous included displays of listing on the water surface, sinking and showing reduced responsiveness during standard training sessions.

The timing of inseminations for the next three animals (females 9-11) was based solely on the presence of a preovulatory follicle. The first two of these females (females 9 and 10) were inseminated three to five times prior to ovulation (Table 3). The third animal (female 11) was inseminated twice beginning $24 \mathrm{~h}$ after behavioral estrous was first detected, but before ovulation. The remaining three animals (females 12 and 13) were inseminated based on the timing of the $\mathrm{LH}$ surge and the presence of a growing preovulatory follicle. All three inseminations were intracornual, occurring in the horn ipsilateral to the ovary with the preovulatory follicle (Table 3). As with the previous estrous cycles, all three exhibited subjective behavioral changes associated with estrous $48-12 \mathrm{hr}$ prior to ovulation. For all trials, the mean number of inseminations per cycle were $1.9 \pm 1.5$ (Table 2). 


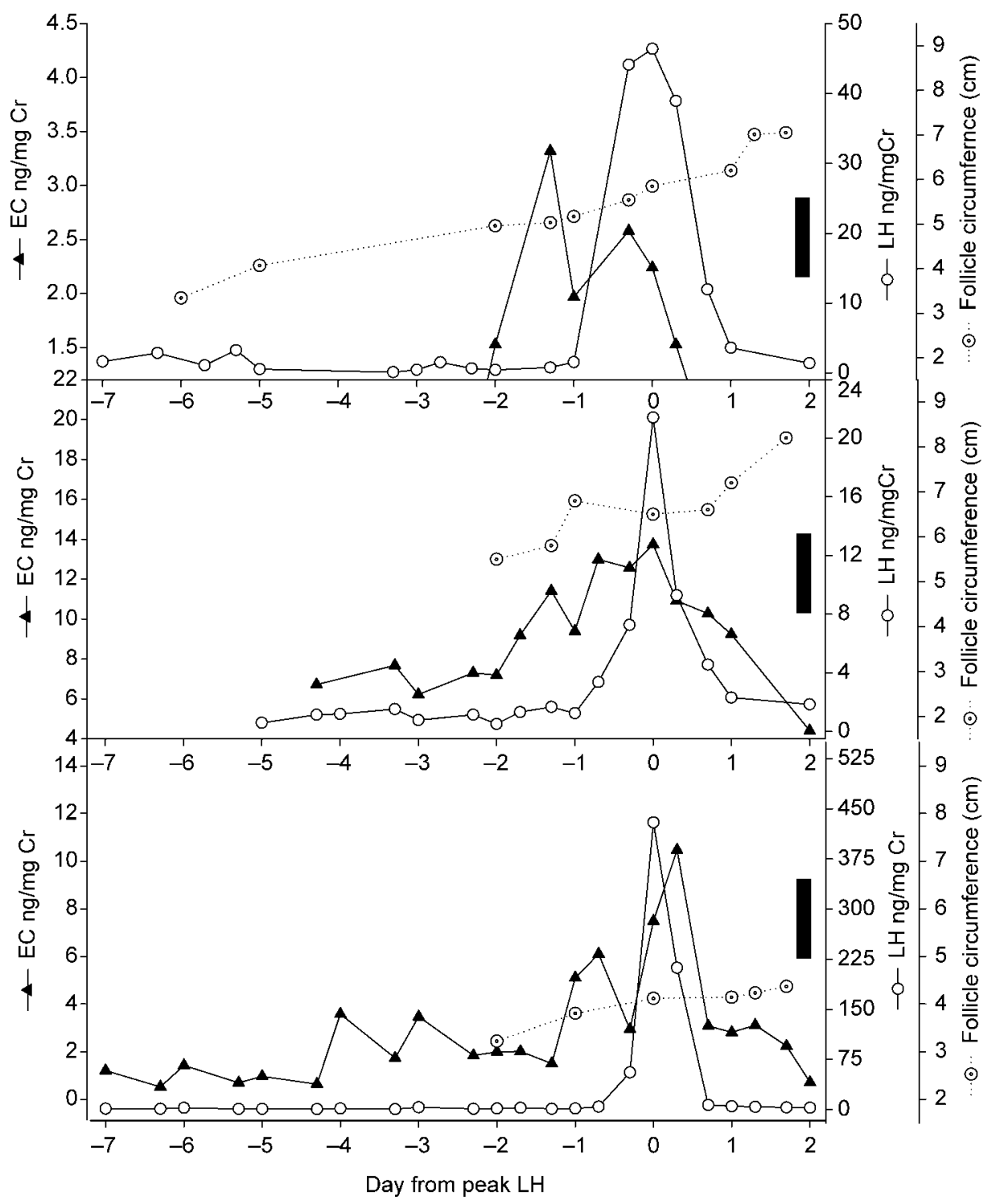

Figure 6 Follicular growth of primary follicles in three animals, female 4 (top graph), female 6 (middle graph) and female 12 (bottom graph), in relationship to urinary $\mathrm{LH}$ and EC. The black bar represents ovulation.

The overall conception rate (liquid stored (1) + cryopreserved semen $(4)=5$ total conceptions/8 estrous periods $\times 100$ ) was $63 \%$. For the two Als using liquid stored semen, the mean number of progressively motile spermatozoa per insemination was $296 \pm 143.7$ and $100 \pm 27.3 \times 10^{7}$ spermatozoa, (females 9 and 10, respectively). For the six Als using frozen-thawed semen, the mean number of progressively motile spermatozoa per insemination was $62.2 \pm 60.5 \times 10^{7}$ spermatozoa. The lowest dose of frozen-thawed progressively motile spermatozoa that resulted in conception was $27 \times 10^{7}$ spermatozoa, and the mean doses for conceptive and non-conceptive Als were $75 \pm 81.0 \times 10^{7}$ and $35.5 \pm 14.8 \times 10^{7}$ spermatozoa, respectively. The conception rate using frozen-thawed spermatozoa was $67 \%$ (4/6; Table 3). The mean time from Al to ovulation in conceptive and non-conceptive cycles was $-2.4 \pm 3.8 \mathrm{~h}$ (range -6.5 to $2 \mathrm{~h}$ ) and $-5.3 \pm 2.1 \mathrm{~h}$ (range -3.0 to $-6.0 \mathrm{~h})$, respectively.

Females 7, 8 and 10 delivered their calves at 373, 361 and 376 days post $\mathrm{Al}$, respectively. Female 11 aborted a fetus at an estimated 135 days post-conception and female 12 was diagnosed as pregnant by ultrasonography at 53 days post-conception.

\section{Discussion}

Successful development of Al procedures for ex-situ management of captive wildlife species first requires fundamental research of female and male reproductive physiology. As one step toward achieving this goal, the current study presents detailed information on 
Table 2 Characteristics of bottlenose dolphin ejaculates used for artificial insemination ${ }^{a}$.

\begin{tabular}{|c|c|c|c|c|c|}
\hline Parameter & $\begin{array}{l}\text { Neat ejaculates } \\
\qquad(n=13)^{b}\end{array}$ & $\begin{array}{c}\text { Liquid stored } \\
(0 \text { to } 24 \mathrm{~h} \text { post } \\
\text { collection; } n=8)^{\mathrm{c}}\end{array}$ & $\begin{array}{c}\text { Pellet post } \\
\text { thaw }(n=3)^{\mathrm{d}}\end{array}$ & $\begin{array}{l}\text { Straws frozen over } \\
\text { liquid nitrogen post } \\
\text { thaw }(n=3)^{\mathrm{e}}\end{array}$ & $\begin{array}{l}\text { Straws frozen } \\
\text { in programmable } \\
\text { freezer }(n=2)^{f}\end{array}$ \\
\hline \multicolumn{6}{|l|}{ Semen characteristic } \\
\hline Volume (ml) & $11.5 \pm 8.5$ & $10.0 \pm 0.0^{\mathrm{g}}$ & $16.7 \pm 2.9^{g}$ & $11.8 \pm 5.5^{\mathrm{g}}$ & $12.0 \pm 2.8^{g}$ \\
\hline $\begin{array}{l}\text { Sperm concentration } \\
\qquad\left(\times 10^{7} \mathrm{ml}^{-1}\right)\end{array}$ & $96.4 \pm 93.4$ & $41.3 \pm 53.8$ & $15.2 \pm 12.1$ & $15.0 \pm 11.3$ & $12.0 \pm 0.0$ \\
\hline $\begin{array}{l}\text { Total spermatozoa per } \\
\quad \text { ejaculate }\left(\times 10^{7} \mathrm{ml}^{-1}\right)\end{array}$ & $572.2 \pm 418.1$ & $173.5 \pm 128.9^{h}$ & $61.1 \pm 32.4^{\mathrm{h}}$ & $85.7 \pm 95.7^{\mathrm{h}}$ & $43.5 \pm 3.5^{\mathrm{h}}$ \\
\hline \multicolumn{6}{|l|}{ Sperm characteristic } \\
\hline $\begin{array}{l}\text { Total progressive } \\
\text { motility }(\%)\end{array}$ & $84.4 \pm 14.5$ & $77.5 \pm 16.6$ & $29.3 \pm 11.5$ & $51.9 \pm 9.8$ & $55.0 \pm 2.8$ \\
\hline Kinetic rating $(0-5)^{\mathrm{i}}$ & $4.9 \pm 0.2$ & $4.6 \pm 0.4$ & $3.8 \pm 0.3$ & $4.8 \pm 0.3$ & $5.0 \pm 0.0$ \\
\hline Sperm motility index ${ }^{j}$ & $415.3 \pm 73.4$ & $92.8 \pm 12.3^{j}$ & $25.7 \pm 12.4^{\mathrm{k}}$ & $56.0 \pm 12.1^{\mathrm{k}}$ & $61.8 \pm 3.2^{\mathrm{k}}$ \\
\hline Viability $(\%)$ & $92.2 \pm 4.9$ & $93.5 \pm 2.8$ & - & $67.7 \pm 6.7$ & $68.6 \pm 19.1$ \\
\hline $\begin{array}{l}{ }^{\mathrm{a}} \text { Values are the means } \pm \text { S.D. } \\
{ }^{\mathrm{b}} \mathrm{A} \text { total of } 13 \text { ejaculates wer } \\
{ }^{\mathrm{c}} \mathrm{A} \text { total of } 8 \text { inseminations } \\
{ }^{\mathrm{d}} \mathrm{A} \text { total of } 6 \text { ejaculates were } \\
\text { ejaculates. } \\
{ }^{\mathrm{e}} \mathrm{A} \text { total of } 2 \text { ejaculates were } \\
{ }^{\mathrm{f}} \mathrm{A} \text { total of } 1 \text { ejaculate was } \mathrm{Cr} \\
{ }^{\mathrm{g}} \text { Final volume of inseminatio } \\
{ }^{\mathrm{h}} \text { Total progressively motile } \mathrm{s} \\
{ }^{\mathrm{i}} \text { Kinetic rating of spermatozo } \\
{ }^{\mathrm{j}} \text { Sperm motility index }=\text { tota } \\
{ }^{\mathrm{k}} \text { Mean percentage of neat sp }\end{array}$ & $\begin{array}{l}\text { llected from } 4 \text { ma } \\
\text { performed using } \\
\text { opreserved and co } \\
\text { opreserved and us } \\
\text { reserved and used } \\
\text { ose. } \\
\text { natozoa per insem } \\
\text { aded subjectively: } \\
\text { gressive motility } \\
\text { motility index for }\end{array}$ & $\begin{array}{l}\text { culates from male 3; } \\
\text { ned during thawing } \\
\text { luring } 3 \text { insemination } \\
\text { ing } 2 \text { inseminations. }\end{array}$ & $\begin{array}{l}\text { ejaculates were } \\
\text { ng } 3 \text { inseminatio }\end{array}$ & $\begin{array}{l}\mathrm{d} \text { for } 24 \mathrm{~h} \text { or less at } 4^{\circ} \\
\text { Semen represent two } \mathrm{p}\end{array}$ & ed cryopreserved \\
\hline
\end{tabular}

the reproductive endocrinology of ten female bottlenose dolphins. By combining this knowledge with previously validated ultrasound technology (Brook 2001), this research has described the temporal relationship between reproductive hormones and ovulation, and applied the information, for the first time in any marine mammal species, to produce live offspring after Al with frozenthawed spermatozoa.

Earlier work focusing on the reproductive cycle of bottlenose dolphins relied on measuring serum concentrations of total estrogens, progesterone and LH. Due to limitations of sampling frequency, it was not possible to adequately describe key endocrine events in the estrous cycle. Previous work characterizing the female reproductive cycle in killer whales using urinary monitoring provided a model for similar investigations in the bottlenose dolphin (Walker et al. 1988, Robeck et al. 1993, 2004).

Individual bottlenose dolphins tend to exhibit distinct reproductive seasonality, which varies depending on the animal's geographic origin (Urian et al. 1996). Bottlenose dolphin species that exhibit polyestrous activity (IndoPacific bottlenose dolphins) exhibit a mean interovulatory interval (as defined by ultrasound) of $30.2 \pm 1.7$ days (Brook 2000). In the present study, the inter-ovulatory interval (defined as the interval between successive LH peaks) in a single Atlantic bottlenose dolphin was 36 days. More work is clearly needed to determine if this difference is due to individual animal variation or to differing characteristics between Indo-Pacific bottlenose dolphin (a tropical species of bottlenose dolphin) and the Atlantic and Pacific bottlenose dolphins (temperate species).

As was described for the killer whale (Robeck et al. 2004), consistent detection of the LH surge appears to require twice daily sample analysis. In fact, the time from baseline to peak LH occurred within $9.4 \pm 3.0 \mathrm{~h}$, which may indicate that even twice-daily sampling (i.e. at $12 \mathrm{~h}$ intervals) may be insufficient for quantifying the LH surge. The period from peak $\mathrm{LH}$ to ovulation in the bottlenose dolphin $(24 \mathrm{~h})$ was $36 \%$ shorter than that for the killer whale (38 h; Robeck et al. 2004).

The ability to accurately detect the timing of the LH surge was critical for developing a reliable indicator of approaching ovulation and timing of $\mathrm{Al}$ in the bottlenose dolphin. Since the preovulatory estrogen peak is temporally broad-based and variable, this measure has limited use for pinpointing the time of ovulation. Conversely, urinary $\mathrm{LH}$ concentrations are basal until the preovulatory $\mathrm{LH}$ surge associated with impending ovulation. Our mobile endocrine laboratory (Steinman et al. 2003), which permits rapid on-site assessments of EC and $\mathrm{LH}$, has eliminated the need to predict ovulation based on follicle size or appearance. As was demonstrated during the Al of females $9-11$, wide individual variation in preovulatory follicle size prevented use of this parameter for predicting ovulation. As a result, more inseminations were required when Al timing was based on follicular size assessments (female 9, 3 inseminations; female 10, 5 inseminations; 
Table 3 Bottlenose dolphin artificial insemination data.

\section{Dates of artificial insemination}

\begin{tabular}{|c|c|c|c|c|c|c|c|c|}
\hline \multirow[b]{2}{*}{ Parameter } & & & & & & & & \\
\hline & 23-05-02 & 23-05-02 & $\begin{array}{c}01-07-02 \text { to } \\
03-07-02\end{array}$ & $03-07-02$ to $06-07-02$ & $\begin{array}{c}06-07-02 \text { to } \\
07-07-02\end{array}$ & 04-10-03 & 08-06-04 & $27-06-04$ \\
\hline Female inseminated & 7 & 8 & 9 & 10 & 11 & 12 & 13 & 12 \\
\hline Cryopreservation method & $\mathrm{Str} / \mathrm{N}_{2}{ }^{\mathrm{a}}$ & $\mathrm{Str} / \mathrm{N}_{2}{ }^{\mathrm{a}}$ & Liquid stored & Liquid stored & Pellets ${ }^{b}$ & Prog. freezer ${ }^{c}$ & $\mathrm{Str} / \mathrm{N}_{2}{ }^{\mathrm{a}}$ & Prog. freezer ${ }^{\mathrm{c}}$ \\
\hline Inseminations per oestrus ${ }^{\mathrm{d}}$ & 1 & 1 & 3 & 5 & 2 & 1 & 1 & 1 \\
\hline Frequency of inseminations (h) & na & na & 12 & 12 & 12 & na & na & na \\
\hline Maximum preovulatory follicle diameter $(\mathrm{cm})$ & 1.7 & 3.1 & 1.9 & 2.1 & 2.4 & 1.89 & 2.29 & 1.43 \\
\hline Maximum preovulatory follicle circumference $(\mathrm{cm})$ & 5.2 & 9.6 & 5.8 & 6.5 & 7.6 & 4.9 & 7.01 & 1.43 \\
\hline Side of ovulation & Left & Left & Right & Right & Left & Left & Left & Left \\
\hline Site of semen deposition during insemination & Uterine body & Uterine body & Uterine body & Uterine body & Uterine body & Left uterine horn & Left uterine horn & Left uterine hor \\
\hline Insemination volume $(\mathrm{ml})$ & 15 & 14.75 & $10,10,10$ & $10,10,10,10,10$ & 15,15 & 10 & 5.5 & 14 \\
\hline 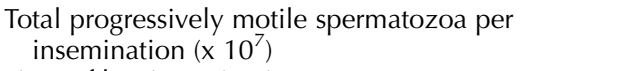 & 36 & 196 & $130,379,379$ & $98,98,87,72,145$ & 65,27 & 46 & 25 & 41 \\
\hline Time of last insemination & 08:30 & 17:00 & 06:00 & 17:00 & 10:00 & $20: 30$ & 00:30 & 11:30 \\
\hline Day of ovulation & 23-05-02 & 23-05-02 & 03-07-02 & $06-07-02$ & 07-07-02 & $05-10-03$ & 08-06-04 & 27-06-04 \\
\hline Estimated time of ovulation & 08:15 & 19:00 & 12:00 & $00: 30$ & $12: 00$ & 03:30 & 03:30 & $11: 30$ \\
\hline The last insemination time to ovulation (h) & +0.30 & +2.0 & -6.0 & -6.0 & -2.0 & -7.0 & -3.0 & -6.5 \\
\hline Peak oestrogen conjugates to ovulation (h) & 16.5 & - & - & - & - & 32 & 34.5 & 23.5 \\
\hline Start of LH surge to ovulation (h) & 23.0 & - & - & - & - & 21.5 & 40 & 40 \\
\hline Peak LH to ovulation (h) & 16.5 & - & - & - & - & 16.0 & 27 & 32 \\
\hline Conception & $\mathrm{Y}$ & $\mathrm{Y}$ & $\mathrm{N}$ & $\mathrm{Y}$ & $\mathrm{Y}$ & $\mathrm{N}$ & $\mathrm{N}$ & $\mathrm{Y}$ \\
\hline Date of parturition & $30-05-03$ & $18-05-03$ & - & 17-07-03 & $15-11-02^{\mathrm{e}}$ & - & - & - \\
\hline Gestation length (d) & 373 & 361 & - & 376 & 135 & - & - & - \\
\hline
\end{tabular}

${ }^{\text {a }} \mathrm{Str} / \mathrm{N}_{2}=$ method 2, straws $(0.5 \mathrm{ml})$ held $4.5 \mathrm{~cm}$ over liquid nitrogen vapor for $10 \mathrm{~min}$ prior to plunging

${ }^{\mathrm{b}}$ Pellets = method 1, $0.2 \mathrm{ml}$ drops of sperm suspension on dry ice (modification of Seager et al. 1981).

${ }^{\mathrm{C}}$ Prog. freezer $=$ method 3 , straws frozen in programmable freezer (Minidigicool, IMV Inernational) as follows: $5^{\circ} \mathrm{C}$ to $-80^{\circ} \mathrm{C}$ at $-100^{\circ} \mathrm{C} \mathrm{min}^{-1} ;-80^{\circ} \mathrm{C}$ to $-140{ }^{\circ} \mathrm{C}$ at $-200^{\circ} \mathrm{C}$ min ${ }^{-1}$ (Robeck \& O'Brien 2004).

× $\quad$ Total number and frequency of inseminations per oestrus period.

e Animal aborted after $132 \mathrm{~d}$ of gestation. 
female 11, 2 insemination per female) than with urinary LH determinations (females 12 and 13, 1 insemination per female).

Altrenogest has been used previously to synchronize estrous in killer whales and Pacific white-sided dolphins (Robeck et al. 2000, 2004). In domestic species, the period from end of altrenogest treatment to ovulation typically approximates the duration of the follicular phase. When altrenogest was administered to bottlenose dolphins for intervals ranging from 29 to 77 days, ovulation occurred 21 days post-withdrawal, which is nearly three times the duration of a normal follicular phase (8 days). A protracted period from hormonal withdrawal to ovulation was also observed in killer whales (25 days) and Pacific white-sided dolphins (21 days). The exact mechanism for this delay in delphinids is unknown, but may reflect differences in follicular recruitment compared with domestic species or duration of altrenogest treatment.

In the horse, altrenogest is most effective at synchronizing estrous during the transitional period and during the breeding season with little or no effect during seasonal anestrous (Webel \& Squires 1982, Squires et al. 1983). Similarly, bottlenose dolphins tend to exhibit seasonal estrous activity from spring to autumn, and this is the time period in which normal altrenogest-induced ovulations occurred (i.e. May to September). While during the remaining months, animals appeared to exhibit a partial response (slight increase in EC without follicular development) to the hormone treatment. Similar partial responses (i.e. estrous behavior, but without ovulation post-altrenogest) have also been observed in horses during the anestrous period (Allen et al. 1980, Squires et al. 1983)

Evaluation of ovaries using trans-abdominal ultrasonography has been previously reported in bottlenose dolphins (Robeck et al. 1998, Brook 2000, 2001) and recently in killer whales (Robeck et al. 2004). Brook (2000, 2001) was the first to describe follicular growth during natural cycles in the Indo-Pacific bottlenose dolphin and reported a POF diameter of $19.9 \pm 1.1 \mathrm{~cm}$. A similar POF size $(2.1 \mathrm{~cm}$ diameter $)$ was found in this study, however, unlike Indo-Pacific bottlenose dolphins, POF size in this study did not increase with body size.

Histological and ultrasonographic evidence suggests that ovulation in bottlenose dolphins occurs predominantly on the left ovary (68-83\%; Ohsumi 1964, Harrison \& Ridgway 1971, Brook 2000). Results herein show that $82 \%$ of the ovulations occurred on the left ovary, thereby providing further support for the aforementioned studies. Similarly to earlier observations (Brook 2000), secondary follicles were observed during the exams, all of which regressed shortly before ovulation.

In addition to the turgid nature of the POF (Brook 2000), a follicle was observed with a stellate appearance (that had been previously turgid and round) whose form preceded the post-ovulation 'donut' ultrasonographic signature seen consistently within hours after ovulation. It is suspected that this was a follicle in the process of ovulating and, if true, ovulation in bottlenose dolphins may occur over a period of less than $30 \mathrm{~min}$ (the time from initial follicle observation to post-ovulatory 'donut' shaped signature. Using once daily observations, Brook (2000) described ovulation as the disappearance of the POF, but the donut signature was not observed. Therefore, it is speculated that the donut signature is probably present for less than $24 \mathrm{~h}$ following ovulation. In agreement with Brook (2000), cavitated CL was observed only during pregnancy.

The raw ejaculate characteristics presented in this paper are similar to those of previous reports (Schroeder \& Keller 1989, Robeck \& O'Brien 2004). In this study, using liquidstored semen, one of two animals conceived when inseminated within $12 \mathrm{~h}$ of ovulation. During the initial trials with liquid-stored semen, no effort was made to establish a minimum insemination dose. Based on the results of this study, it appears that if using liquid stored semen, fewer than 200 million progressively motile spermatozoa can be used for intrauterine $\mathrm{Al}$ in bottlenose dolphins.

Although not directly comparable, post-thaw sperm quality was highest using the programmable freezer in TYB extender. These results are in agreement with the recent report describing this method (Robeck \& O'Brien 2004). Despite the variations in post-thaw motility among the cryopreservation methods employed in this study, all resulted in conceptions. These results suggest that less technological alternatives for banking bottlenose dolphin spermatozoa, such as pelleting sperm on dry ice or freezing sperm in straws over liquid nitrogen (in association with the appropriate cooling and freezing rates), can be used to successfully produce offspring following Al with frozen-thawed spermatozoa.

$\mathrm{Al}$ in bottlenose dolphins was first attempted by Schroeder \& Keller (1990). That report described using an endoscope to deposit spermatozoa in the vaginal fold, just distal to the cervix (also called the spermathecal recess or pseudocervix). The lack of established pregnancies in this report led to speculation that intrauterine sperm placement would be required for $\mathrm{Al}$ in this species (Robeck et al. 1994). The unique structure of the dolphin cervix and pseudocervix (Green 1977, Robeck et al. 1994) requires an endoscope to gain access to the uterus. Accordingly, Al trials conducted previously (FM Brook et al., unpublished, Robeck et al. 2001) and herein demonstrated that access to the cervix and uterus was possible providing that the pseudocervical opening could be adequately visualized.

During the development and improvement of the $\mathrm{Al}$ procedures described in the paper, the goals of the research were to improve the timing of $\mathrm{Al}$, and as a consequence reduce the number of inseminations required per estrous and the number of spermatozoa required for each insemination trial. The development of the rapid onsite LH assay system improved the investigators' ability to time the inseminations around ovulation, resulting in offspring production following a single insemination. While the minimum dose of frozen-thawed spermatozoa required 
for successful Al is unknown for the bottlenose dolphin, this study demonstrates that conception can occur from a dose as low as $\mathbf{2 7 0}$ million progressively motile spermatozoa. Defining the lowest dose of spermatozoa necessary for conception will be the focus of continued research.

Previous research had established effective methodologies for the long-term storage of bottlenose dolphin spermatozoa and now these data have demonstrated the capability to produce offspring following Al using cryopreserved semen. This is an important milestone for the captive genetic management of bottlenose dolphins and this study highlights the value of strategic and systematic investigation into the basic reproductive physiology of a wildlife species to allow the development of assisted reproductive technologies.

\section{Acknowledgements}

The veterinary, animal laboratory, animal care and animal training staff at SeaWorld Florida and SeaWorld California, Kamogawa Sea World, US Navy Marine Mammal Program, Dolphin Quest and Genoa Aquarium for their consistent support in making this research possible. We especially thank Tom Reidarson and Todd Schmitt (SeaWorld California), and Maddalena lannaccone (Acquario di Genova) for their assistance with ultrasound data collection. We thank Satoshi Inoue (Kamogawa Sea World), Britt Swenberg (USNMMP) and Todd Ryan (SeaWorld California) for their help with the semen collection. We also thank Bill Hoffman (SeaWorld San Diego) for support with the urine collection training. We thank Brad Andrews (SeaWorld Inc) for his continued support of this project. Finally, we thank and recognize the late Teruo Tobayama (Kamogawa Sea World) for his support for and interest in this work. This project was funded by SeaWorld Corporation and is a SeaWorld Technical contribution Number 2004-03-T.

\section{References}

Allen WR, Urwin V, Simpson DJ, Greenwood RE, Crowhurst RC, Ellis DR, Ricketts SW, Hunt MD \& Digby NJ 1980 Preliminary studies on the use of an oral progestogen to induce estrous and ovulation in seasonally anoestrous thoroughbred mares. Equine Veterinary Journal 12 141-145.

Brook FM 2000 Sonographic testicular and ovarian assessment in the bottlenose dolphin, Tursiops truncatus aduncus. In The Bottlenose Dolphin Breeding Workshop, pp 7-15. Eds D Duffield \& TR Robeck. Silver Springs, MD, USA: AZA Marine Mammal Taxon Advisory Group.

Brook FM 2001 Sonographic imaging of the reproductive tract of the female bottlenose dolphin. Tursiops truncatus aduncas. Reproduction $121419-428$.

Benirschke K, Johnson ML \& Benirschke RJ 1980 Is ovulation in dolphins, Stenella longirostris and Stenella attenuata, always copulation induced? Fisheries Bulletin 78 507-528.

Cornell LH, Asper ED, Antrim JE, Osborn K \& Gurevich VS 1977 Experiences of Sea World from 1963 to present with Tursiops species reproduction and some plans for the future. In Breeding Dolphins: Present Status, Suggestions for the Future, pp 273-673. Eds SH Ridgway \& K Benirschke. Washington, DC, USA: US Dept of Commerce, NTIS PB-273-673.

Cornell LH, Asper ED, Antrim JE, Searles SS, Young WG \& Goff T 1987 Progress report: results of a long-range captive breeding program for the bottlenosed dolphin, Tursiops truncatus and Tursiops truncatus gilli. Zoo Biology 6 41-53.

Duffield DA, Odell DK, McBain JF \& Andrews B 1995 Killer whale (Orcinus orca) reproduction at Sea World. Zoo Biology 14 417-430.

Duffield DA, Shell ED \& Dudley M 2000 Demographic analysis of breeding bottlenose dolphins in North American zoological facilities: 1976-1998. In The Bottlenose Dolphin Breeding Workshop, pp 139-155. Eds D Duffield \& TR Robeck. Silver Springs, MD, USA: AZA Marine Mammal Taxon Advisory Group.

Durrant B, Russ K, Proulx J, Reddy M \& Ridgway S 2000 Current techniques for semen cryopreservation in bottlenose dolphins (Tursiops truncatus). In The Bottlenose Dolphin Breeding Workshop, pp 239-247. Eds D Duffield \& TR Robeck. Silver Springs, MD, USA: AZA Marine Mammal Taxon Advisory Group.

Graham L, Schwarzenberger F, Möstl E, Galama W \& Savage A 2001 A versatile enzyme immunoassay for the determination of progestogens in faeces and serum. Zoo Biology 20 227-236.

Graham LG, Boling J, Miller G, Pratt-Hawkes N \& Joseph S 2002 Enzyme-immunoassay for the measurement of luteinizing hormone in the serum of African elephants (Loxodonta africana). Zoo Biology 21 403-408.

Green RF 1977 Anatomy of the reproductive organs in dolphins. In Breeding Dolphins: Present Status, Suggestions for the Future, pp 185-191. Eds SH Ridgway \& K Benirschke. Benirschke. Washington, DC, USA: US Department of Commerce, NTIS PB-273-673.

Harrison RJ \& Ridgway SH 1971 Gonadal activity in some bottlenose dolphins (Tursiops truncatus). Journal of Zoology 165 355-366.

Holt WV, Bennet PM, Volobouev V \& Watson PF 1996 Genetic resource banks in wildlife conservation. Journal of the Zoological Society of London 238 531-544.

Keller KV 1986 Training of the Atlantic bottlenose dolphins (Tursiops truncates) for artificial insemination. International Association of Aquatic Animal Medicine $1422-24$.

Kirby VL 1990 Endocrinology of marine mammals. In Handbook of Marine Mammal Medicine: Health, Disease, and Rehabilitation, pp 303-351. Eds LA Dierauf \& FL Boca Raton. Boca Raton, FL, USA: CRC Press.

Kirby VL \& Ridgway SH 1984 Hormonal evidence of spontaneous ovulation in captive dolphins (Tursiops truncatus and Delphinus delphis). International Whale Commission Special Issue $\mathbf{6}$ 459-464.

Kraeling RR, Dziuk PJ, Pursel VG, Rampacek GB \& Webel SK 1981 Synchronisation of estrus in swine with ally trenbolone (RU-2267). Journal Animal Science 52 831-835.

Lenzi R 2000 Operant conditioning and ultrasound together at work to successfully condition voluntary urine collection. Conference Proceedings of the International Marine Animal Trainer Association Abstract 17.

Ohsumi S 1964 Comparison of maturity and accumulation rate of corpora albacantia between the left and right ovaries in cetacean. Tokyo Whale Research Institute 18 123-149.

Robeck TR, Curry BE, McBain JF \& Kraemer DC 1994 Reproductive biology of the bottlenose dolphin (Tursiops truncatus) and the potential application of advanced reproductive technologies. Journal of Zoo Wildlife Medicine 25 321-336.

Robeck TR, Atkinson S \& Brook F 2001 Reproduction. In CRC Handbook in Marine Mammal Medicine, 2nd edn, ch 11, pp 193-236. Eds L Dierauf \& F Gulland. Boca Raton, FL, USA: CRC Press.

Robeck TR, Jensen E, Brook F, Rouke N, Rayner C \& Kinoshita R 2000 Preliminary investigations into ovulation manipulation techniques in delphinids. Proceedings of the American Association of Zoo Animal Veterinarians and International Association of Aquatic Animal Medicine 31 222-225.

Robeck TR, Greenwell M, Boehm JR, Yoshioka M, Tobayama T, Steinman K \& Monfort ST 2003 Artificial insemination using frozen-thawed semen in the pacific white-sided dolphin (Lagenorhynchus obliquidens). Proceedings International Association of Aquatic Animal Medicine 34 50-54. 
Robeck TR, McBain JF, Mathey S \& Kraemer DC 1998 Ultrasonographic evaluation of the effects of exogenous gonadotropins on follicular recruitment and ovulation induction in the Atlantic bottlenose dolphin (Tursiops truncatus). Journal of Zoo and Wildlife Medicine 29 6-13.

Robeck TR \& O'Brien JK 2004 Effect of cryopreservation methods and pre-cryopreservation storage on bottlenose dolphin (Tursiops truncates) spermatozoa. Biology of Reproduction 70 1340-1348.

Robeck TR, Schneyer AL, McBain JF, Dalton LM, Walsh MT, Czekala NM \& Kraemer DC 1993 Analysis of urinary immunoreactive steroid metabolites and gonadotropins for characterization of the estrous cycle, breeding period and seasonal estrous activity of captive killer whales (Orcinus orca). Zoo Biology 12 173-187.

Robeck TR, Steinman KJ, Gearhart S, Reidarson TR, McBain JF \& Monfort SL 2004 Reproductive physiology and development of artificial insemination technology in killer whales (Orcinus orca). Biology of Reproduction 71 650-660.

Sawyer-Steffan JE \& Kirby VL 1980 A study of serum steroid hormone levels in captive female bottlenose dolphins, their correlation with reproductive status, and their application to ovulation induction in captivity. Springfield, VA, USA: National Technical Information Services, PB80-177199.

Sawyer-Steffan JE, Kirby VL \& Gilmartin WC 1983 Progesterone and estrogens in the pregnant and non-pregnant dolphin, Tursiops truncatus, and the effects of induced ovulation. Biology of Reproduction 28 897-901.

Schneyer AL, Castro A \& Odell D 1985 Radioimmunoassay of serum $\mathrm{FSH}$ and $\mathrm{LH}$ in the bottlenosed dolphin. Biology of Reproduction 33 844-853.

Schroeder JP 1990 Reproductive aspects of marine mammals. In Handbook of Marine Mammal Medicine: Health, Disease, and Rehabilitation, pp 353-369. Ed. LA Dierauf. Boca Raton, FL, USA: CRC Press.

Schroeder JP \& Keller KV 1989 Seasonality of serum testosterone levels and sperm density in Tursiops truncates. Journal of Experimental Zoology 249 316-321.

Schroeder JP \& Keller KV 1990 Artificial insemination of bottlenose dolphins. In The Bottlenose Dolphin, ch26, pp 447-460. Eds S Leatherwood \& RR Reeves. San Diego, CA, USA: Academic Press.

Seager S, Gilmartin W, Moore L, Platz C \& Kirby V 1981 Semen collection (electroejaculation), evaluation and freezing in the Atlantic bottlenosed dolphin (Tursiops truncatus). Proceedings of the American Association of Zoo Veterinarians Abstract 136.

Squires EL, Stevens WB, McGlothlin DE \& Pickett NW 1979 Effects of an oral progestin on the estrous cycle and fertility of mares. Journal of Animal Science 49 729-735.

Squires EL, Heesman CP, Webel SK, Schideler RK \& Voss JL 1983 Relationship of altrenogest to ovarian activity, hormone concentrations and fertility in mares. Journal of Animal Science $\mathbf{5 6}$ 901-910.
Steinman KJ, Monfort SL, Jensen E, Sweeney J \& Robeck TR 2003 The use of mobile endocrine laboratory to assess reproductive status and time artificial insemination in captive cetaceans. Proceedings International Association of Aquatic Animal Medicine 34 $45-49$.

Stevenson JS \& Davis DL 1982 Estrous synchronization and fertility in gilts after 14- or 18-day feeding of altrenogest beginning at estrus or diestrus. Journal of Animal Science 55 119-123.

Taussky HH 1954 A microcolorimetric determination of creatine in urine by the Jaffe reaction. Journal of Biological Chemistry 208 853-861.

Urian KW, Duffield DA, Read AJ, Wells RS \& Shell ED 1996 Seasonality of reproduction on bottlenose dolphins, Tursiops truncates. Journal Mammalogy 77 394-403.

Walker LA, Cornell L, Dahl KD, Czekala NM, Dargen CM, Joseph BE, Hsueh AJW \& Lasley BL 1988 Urinary concentrations of ovarian steroid hormone metabolites and bioactive follicle stimulating hormone in killer whales (Orcinus orcus) during ovarian cycles and pregnancy. Biology of Reproduction 39 1013-1020.

Webel SK \& Squires EL 1982 Control of the estrous cycle in mares with altrenogest. Journal of Reproduction and Fertility Suppl 32 193-198.

Wells R 2000 Reproduction in wild bottlenose dolphins: overview of patterns observed during a long-term study. In The Bottlenose Dolphin Breeding Workshop, pp 57-73. Eds D Duffield \& TR Robeck. Silver Springs, MD: AZA Marine Mammal Taxon Advisory Group.

Wildt DE, Schiewe MC, Schmidt PM, Goodrowe K, Philips JG, O'Brien S \& Bach M 1986 Developing animal model systems for embryo technologies in rare and endangered wildlife. Theriogenology $2533-51$.

Wildt DE, Rall WF, Critser JK, Monfort SL \& Seal US 1997 Genome resource banks: 'living collections' for biodiversity conservation. Bioscience 47 689-698.

Young SJF \& Huff DG 1996 Fertility management in a female killer whale (Orcinus orca) with altrenogest (Regu-mate). Proceedings International Association of Aquatic Animal Medicine $\mathbf{2 7}$ Abstract 66.

Yoshioka M, Mohri E, Tobayama T, Aida K \& Hanyu I 1986 Annual changes in serum reproductive hormone levels in captive female bottlenose dolphins. Bulletin of the Japanese Society of Scientific Fisheries 11 1939-1946.

Received 5 October 2004

First decision 22 November 2004

Revised manuscript received 9 December 2004

Accepted 4 February 2005 